\title{
Emission Testing of Washington Metropolitan Area Transit Authority (WMATA) Natural Gas and Diesel Transit Buses
}

Technical Report NREL/TP-540-36355

December 2005

M. Melendez, J. Taylor, and J. Zuboy National Renewable Energy Laboratory

W.S. Wayne

West Virginia University

D. Smith

U.S. Department of Energy

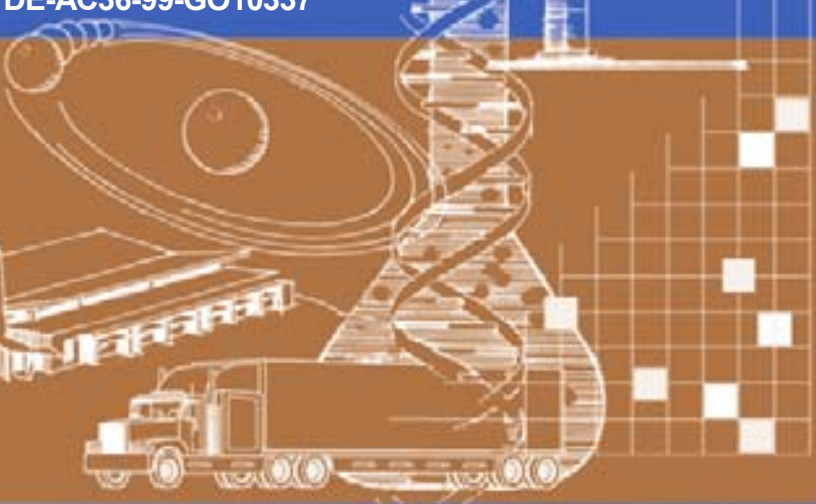


Emission Testing of Washington Metropolitan Area Transit Authority (WMATA) Natural Gas and Diesel Transit Buses

M. Melendez, J. Taylor, and J. Zuboy National Renewable Energy Laboratory

W.S. Wayne

West Virginia University

D. Smith

U.S. Department of Energy

Prepared under Task No. FC05-9000
Technical Report NREL/TP-540-36355

December 2005

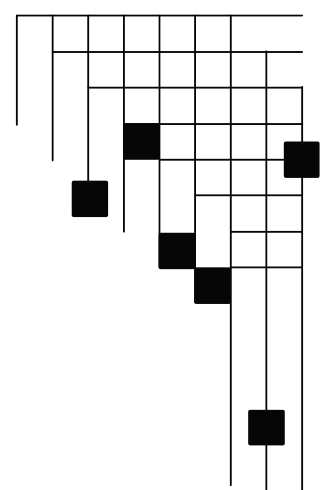




\section{NOTICE}

This report was prepared as an account of work sponsored by an agency of the United States government. Neither the United States government nor any agency thereof, nor any of their employees, makes any warranty, express or implied, or assumes any legal liability or responsibility for the accuracy, completeness, or usefulness of any information, apparatus, product, or process disclosed, or represents that its use would not infringe privately owned rights. Reference herein to any specific commercial product, process, or service by trade name, trademark, manufacturer, or otherwise does not necessarily constitute or imply its endorsement, recommendation, or favoring by the United States government or any agency thereof. The views and opinions of authors expressed herein do not necessarily state or reflect those of the United States government or any agency thereof.

Available electronically at http://www.osti.gov/bridge

Available for a processing fee to U.S. Department of Energy and its contractors, in paper, from:

U.S. Department of Energy

Office of Scientific and Technical Information

P.O. Box 62

Oak Ridge, TN 37831-0062

phone: 865.576 .8401

fax: 865.576 .5728

email: mailto:reports@adonis.osti.gov

Available for sale to the public, in paper, from:

U.S. Department of Commerce

National Technical Information Service

5285 Port Royal Road

Springfield, VA 22161

phone: 800.553 .6847

fax: 703.605.6900

email: orders@ntis.fedworld.gov

online ordering: http://www.ntis.gov/ordering.htm 


\section{Table of Contents}

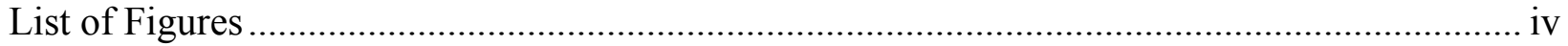

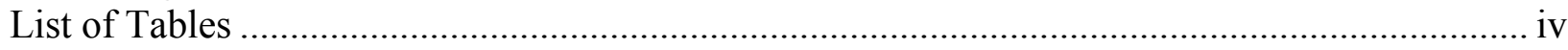

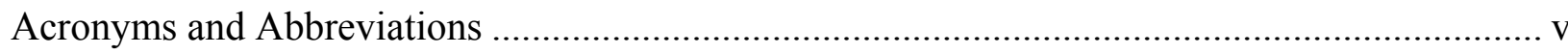

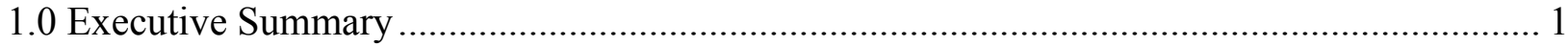

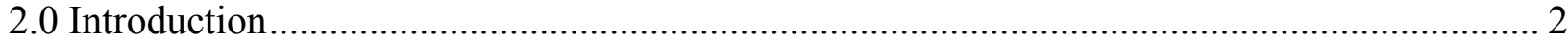

2.1 WMATA's Clean Bus Choices...................................................................................... 3

2.2 Emission Testing of WMATA's CNG and Diesel Buses ............................................... 3

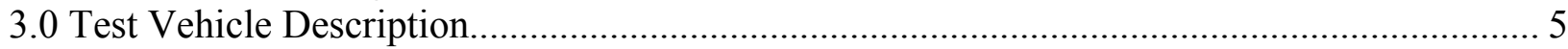

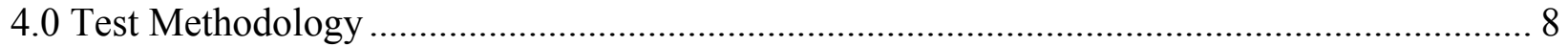

4.1 WVU Laboratory Description and Analysis of Emissions .......................................... 8

4.2 NREL Laboratory Description and Analysis of Unregulated Emissions ......................... 10

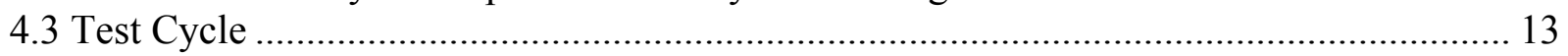

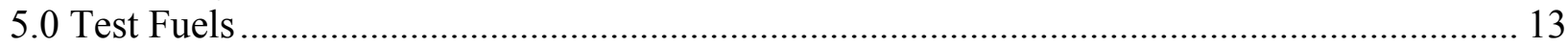

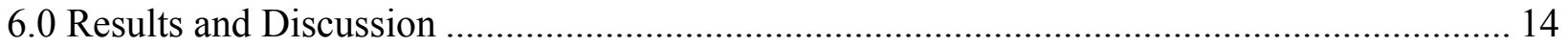

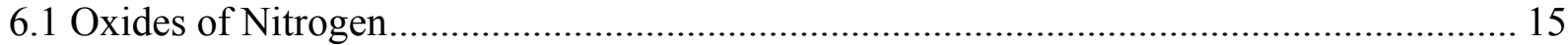

6.2 Particulate Matter............................................................................................... 18

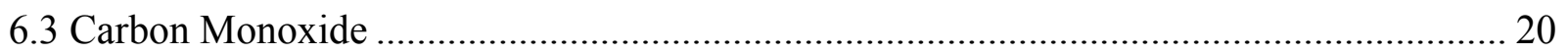

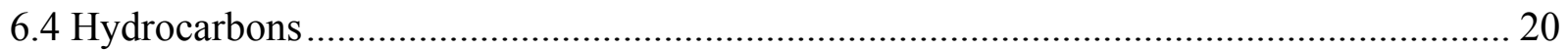

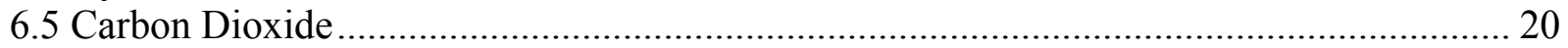

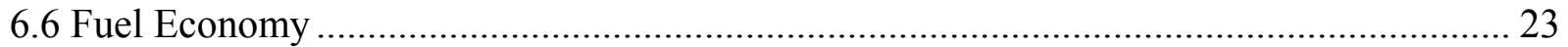

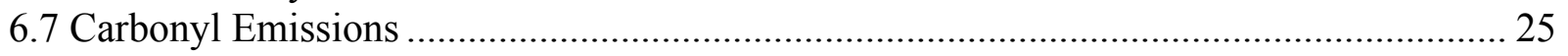

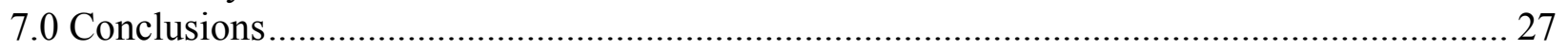

7.1 Regulated Emissions and Fuel Economy................................................................... 27

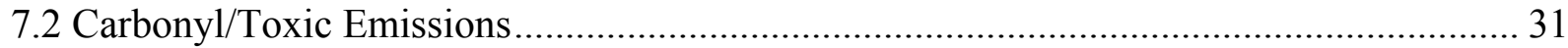

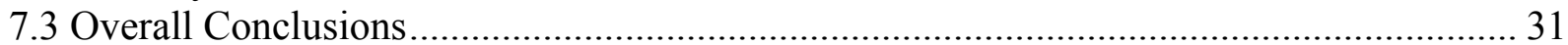

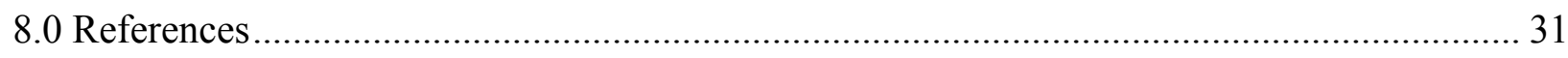

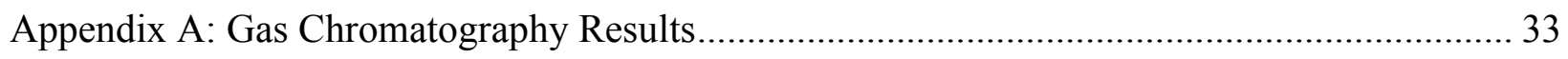




\section{List of Figures}

Figure 1: Results of WMATA Emission Testing Program, Phase I, Central Business District

Drive Cycle.....

Figure 2: MY 2000 Orion Model 06.501 Bus with MY 2000 DDC Series 50 Diesel Engine ....... 6

Figure 3: MY 1992 Orion Model 06.501 Bus with MY 2004 DDC Series 50 Engine and EGR... 7

Figure 4: MY 2001 New Flyer C40LF Bus with MY 2001 CWI C Gas Plus CNG Engine......... 7

Figure 5: MY 2001 New Flyer C40LF Bus with MY 2004 John Deere 6081H CNG Engine....... 8

Figure 6: Bus under Test on the WVU TransLab Chassis Dynamometer.................................. 9

Figure 7: Sample Output from the HPLC for a Calibration Standard Using the Method Defined

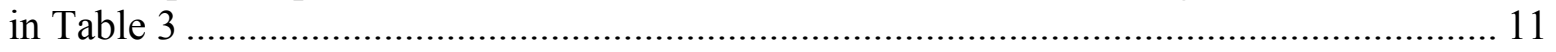

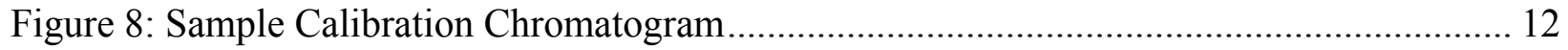

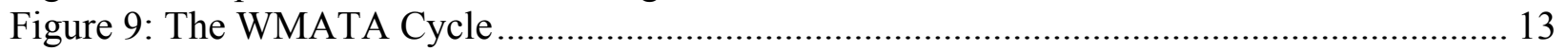

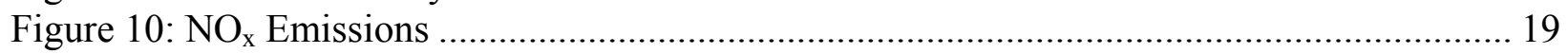

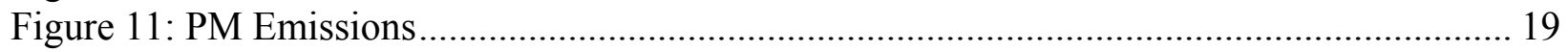

Figure 12: CO Emissions .............................................................................................. 21

Figure 13: THC (Diesel Vehicles) and NMHC (CNG Vehicles) Emissions............................. 21

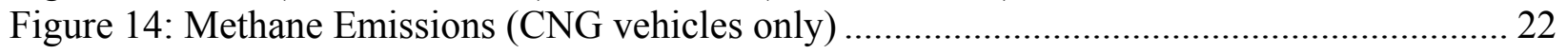

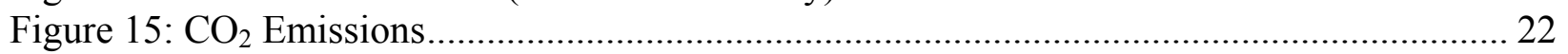

Figure 16: Diesel Energy Equivalent Fuel Economy ...................................................... 24

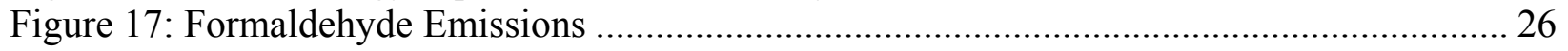

Figure 18: Acetaldehyde Emissions.................................................................................... 28

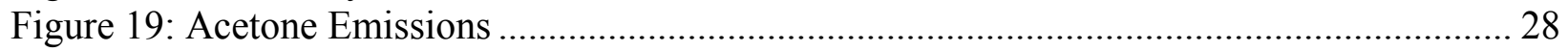

\section{List of Tables}

Table 1: Vehicles Tested in Phase I of WMATA Emission Testing Program ............................ 4

Table 2: Vehicles Tested in Phase II of WMATA Emission Testing Program ............................. 5

Table 3: HPLC Analytical Method for Carbonyls (Aldehydes and Ketones) ........................... 10

Table 4: GC Analytical Method for Hydrocarbons ............................................................. 12

Table 5: WMATA Compressed Natural Gas Properties, April 2004 ...................................... 14

Table 6: WMATA Diesel Properties, June 2004 .............................................................. 15

Table 7: Summary of Emission Results............................................................................. 16

Table 8: Calculation of the Carbon Weight Fraction $\left(\mathrm{R}_{\text {fuel }}\right)$ for $\mathrm{CNG}$.................................... 23

Table 9: Calculation of Energy Equivalent Fuel Economy ................................................. 24

Table 10: Diesel Vehicle Carbonyl Emissions (mg/mi) ....................................................... 29

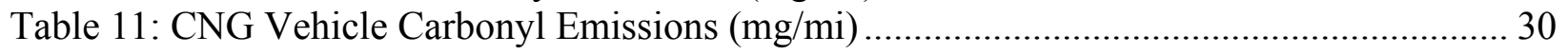




\section{Acronyms and Abbreviations}

BDL

BTEX

CARB

CBD

CFR

$\mathrm{CH}_{4}$

$\mathrm{CNG}$

$\mathrm{CO}$

$\mathrm{CO}_{2}$

CWI

DDC

DNPH

DPF

EGR

EPA

FID

g/bhp-hr

GC

$\mathrm{gC}$

GVWR

$\mathrm{HC}$

HEPA

HPLC

mi

mpeg

MY

NDIR

NMHC

$\mathrm{NO}$

$\mathrm{NO}_{\mathrm{x}}$

NREL

PM

ppmC

PSI

PSIA

ReFUEL

THC

TransLab

ULS (ULSD)

WMATA

WVU
Below detection limit

Benzene, toluene, ethylbenzene, and xylene isomers

California Air Resources Board

Central Business District (drive cycle)

Code of Federal Regulations

Methane

Compressed natural gas

Carbon monoxide

Carbon dioxide

Cummins Westport Inc.

Detroit Diesel Corporation

2,4-Dinitrophenylhydrazine

Diesel particulate filter

Exhaust gas recirculation

U.S. Environmental Protection Agency

Flame ionization detection

Grams per brake horsepower-hour

Gas chromatograph

Grams of carbon

Gross vehicle weight rating

Hydrocarbons

High efficiency particulate air (filters)

High-performance liquid chromatography

Miles

Miles per (diesel) equivalent gallon

Model year

Non-dispersive infrared analyzers

Non-methane hydrocarbons

Nitrogen oxide

Oxides of nitrogen

National Renewable Energy Laboratory

Particulate matter

Parts per million carbon

Pounds per square inch

Absolute PSI

Renewable Fuels and Lubricants (Laboratory)

Total hydrocarbons

WVU Transportable Heavy-Duty Vehicle Emissions Testing Laboratory

Ultra low sulfur diesel

Washington Metropolitan Area Transit Authority

West Virginia University 


\subsection{Executive Summary}

Natural gas is a domestically available resource. The U.S. Department of Energy (DOE) supports natural gas vehicle research, development, deployment, and evaluation through its FreedomCAR and Vehicle Technologies Program to help the United States reduce its dependence on imported petroleum and to pave the way to a future transportation network based on hydrogen.

Historically, natural gas vehicles have exhibited lower emissions of regulated pollutants compared with vehicles powered by conventional fuels such as gasoline and diesel. However, this has come into question recently in light of increasingly stringent U.S. Environmental Protection Agency (EPA) regulations that all heavy-duty engines (including diesel engines) will have to meet. Cleaner diesel engine technologies are being introduced. The question is, "Are cleaner natural gas engine technologies being introduced that can still demonstrate emission reduction benefits by comparison?" This is of particular interest to transit fleets currently operating natural gas buses and, having already invested in natural gas refueling infrastructure, interested in expanding their fleet or buying new buses.

In 2004, DOE's National Renewable Energy Laboratory (NREL) led an evaluation of the emissions of transit buses operated by the Washington Metropolitan Area Transit Authority (WMATA). The goal of this project was to evaluate the emissions of natural gas transit buses and the improving baseline emissions of comparable diesel buses with advanced emission control technologies (both of which were operating in the regular WMATA fleet). The project was performed in cooperation with DOE's Clean Cities Program, which supports partnerships that reduce petroleum consumption through alternative fuels and vehicles, fuel blends, improved fuel economy, hybrid vehicles, and idle reduction.

The Washington Metropolitan Area Transit Authority serves the public transportation needs of metropolitan Washington, D.C., including Northern Virginia and Southern Maryland. Because the EPA has classified this area as a severe ozone non-attainment area, WMATA is continually working to reduce local air pollution while providing reliable, low-cost service to its customers. A variety of low-emission bus technologies can help WMATA, and other transit agencies, achieve these goals. Among these options are compressed natural gas (CNG) buses and lowsulfur diesel buses equipped with advanced emission control technologies.

A total of twelve 40-foot, low-floor WMATA buses were tested using West Virginia University's Transportable Heavy-Duty Vehicle Emission Testing Laboratory. These buses were of two types: CNG and low-sulfur diesel (approximately 17 ppm sulfur). All CNG buses had lean burn natural gas engines and oxidation catalysts. All diesel buses had catalyzed particulate filters, and one group of diesel buses had exhaust gas recirculation (EGR).

The buses were tested for numerous regulated and unregulated emissions, including hydrocarbons, carbon monoxide, oxides of nitrogen $\left(\mathrm{NO}_{\mathrm{x}}\right)$, particulate matter $(\mathrm{PM})$, and various toxic emissions. The increasingly strict EPA and California standards set for $\mathrm{NO}_{\mathrm{x}}$ and $\mathrm{PM}$, particularly $\mathrm{NO}_{\mathrm{x}}$, are considered to be the greatest challenge for heavy-duty engines. $\mathrm{NO}_{\mathrm{x}}$ is also of particular concern to the Metropolitan Washington, D.C., area because this area's ozone problem is considered to be largely $\mathrm{NO}_{\mathrm{x}}$ limited. As such, most of its air quality control measures are focused on an overall $\mathrm{NO}_{\mathrm{x}}$ reduction strategy. All buses were tested over the WMATA cycle, a custom drive cycle designed to represent real-world operation of the WMATA buses. 
The following are the four test bus configurations included in the study:

- CNG buses with model year (MY) 2004 John Deere 6081H engines, equipped with oxidation catalysts

- CNG buses with MY 2001 Cummins Westport, Inc. (CWI) C Gas Plus engines, equipped with oxidation catalysts

- Diesel buses with MY 2004 Detroit Diesel Corporation (DDC) Series 50 engines, equipped with catalyzed particulate filters and EGR

- Diesel buses with MY 2000 DDC Series 50 engines, equipped with catalyzed particulate filters.

The John Deere CNG buses produced $49 \%$ lower $\mathrm{NO}_{\mathrm{x}}$ emissions and $84 \%$ lower PM emissions compared with the MY 2004 DDC diesel buses, and $63 \%$ lower $\mathrm{NO}_{\mathrm{x}}$ emissions and $60 \%$ lower PM emissions compared with the MY 2000 DDC diesel buses. The CWI buses produced $6.1 \%$ higher $\mathrm{NO}_{\mathrm{x}}$ emissions and 60\% lower PM emissions compared with the MY 2004 DDC diesel buses, and 23\% lower $\mathrm{NO}_{\mathrm{x}}$ emissions and equal PM emissions compared with the MY 2000 DDC diesel buses.

In addition to showing the emissions advantage of CNG buses, this project showed promising fuel economy results for the CNG buses compared with the diesel buses. The following fuel economy comparisons are made on a diesel gallon equivalent basis. The John Deere CNG buses exhibited a 9.0\% fuel economy improvement compared with the MY 2004 DDC diesel buses and a $2.9 \%$ improvement compared with the MY 2000 DDC diesel buses. The CWI CNG buses exhibited a fuel economy 4.2\% higher than the MY 2004 DDC diesel buses and 1.6\% lower than the MY 2000 DDC diesel buses. Both CNG engines use lean burn technology.

Formaldehyde and acetaldehyde emissions from the diesel buses and the John Deere CNG buses were very low, approaching ambient background levels. The CWI CNG buses produced formaldehyde and acetaldehyde emissions that were above ambient background levels and markedly higher than the other bus groups. This result may indicate a malfunction with the exhaust catalyst or a maintenance/durability issue, neither of which could be verified in time for inclusion in this report.

Other carbonyl emissions were not detected at levels that could be distinguished from ambient background, indicating that the levels are extremely low for these emissions from all vehicles tested. An attempt was made to characterize 1,3-butadiene and BTEX (benzene, toluene, ethylbenzene, and xylene isomers) emissions. However, the gas chromatography equipment available for this study did not have sufficient sensitivity to detect the low levels of 1,3-butadiene and BTEX in the vehicle exhaust.

\subsection{Introduction}

Because natural gas is a domestically available resource, the U.S. Department of Energy (DOE) supports natural gas vehicle research, development, deployment, and evaluation through its FreedomCAR and Vehicle Technologies Program. The main goal is to help the United States reduce its dependence on imported petroleum. Other goals include improving air quality in U.S. cities and advancing gaseous fuel technology to pave the way to a future transportation network based on hydrogen. 
The goal of this project was to evaluate the emissions of natural gas transit buses and the emissions of diesel buses with advanced emission control technologies. The project was performed in cooperation with DOE's Clean Cities Program, which supports partnerships that reduce petroleum consumption through alternative fuels and vehicles, fuel blends, improved fuel economy, hybrid vehicles, and idle reduction.

The project was led by DOE's National Renewable Energy Laboratory (NREL) with the support of West Virginia University's National Research Center for Alternative Fuels, Engines, and Emissions (WVU). Since 1993, NREL has evaluated advanced technology alternative fuel and diesel trucks and buses nationwide. The resulting data are used to evaluate technologies and assist vehicle operators in selecting, purchasing, and maintaining their fleets. NREL has worked with WVU for many years in support of this purpose. Over the past 11 years, the WVU Transportable Heavy-Duty Vehicle Emissions Testing Laboratory (TransLab) has been used to measure exhaust emissions from more than 700 conventional and alternative fuel heavy-duty trucks and buses.

\subsection{WMATA's Clean Bus Choices}

Various vehicle choices are available to transit fleets that are balancing the goals of improving local air quality, achieving high customer satisfaction, and maintaining fiscal responsibility. The number of choices is increasing as heavy-duty engine manufacturers work toward meeting the stringent 2007/2010 U.S. Environmental Protection Agency (EPA) emission regulations. Choices include buses fueled with alternative fuels such as natural gas and biodiesel, buses equipped with advanced emission control devices and fueled with low-sulfur diesel, and hybrid electric buses fueled with conventional or alternative fuels.

These choices are critical for the Washington Metropolitan Area Transit Authority (WMATA), which serves 3.5 million people in the metropolitan Washington, D.C., area. More than 1.7 million commuters rely on WMATA's rail cars and transit buses daily, including 348 bus routes with more than 1,400 buses. The EPA has classified the Washington, D.C., metropolitan area as a severe ozone non-attainment area. Oxides of nitrogen $\left(\mathrm{NO}_{\mathrm{x}}\right)$ emissions are of particular concern because the area's ozone problem is considered to be largely $\mathrm{NO}_{\mathrm{x}}$ limited. As such, most of the area's air quality control measures are focused on an overall $\mathrm{NO}_{\mathrm{x}}$ reduction strategy.

The air pollution in Washington, D.C., is primarily due to motor vehicle emissions. To reduce the area's vehicular emissions, WMATA is tasked with providing low-cost, reliable transportation in the cleanest way possible. Under the current operating plan, approximately 400 of WMATA's buses will be fueled with compressed natural gas (CNG), and the rest, roughly 1,400 vehicles, will be fueled with low-sulfur diesel (approximately $17 \mathrm{ppm}$ sulfur).

\subsection{Emission Testing of WMATA's CNG and Diesel Buses}

A two-phase emission test program was designed to evaluate the performance of WMATA's CNG and diesel buses. WMATA is using the test results to compare its CNG and diesel buses, which will aid in planning of future bus acquisitions. The results will help other transit agencies evaluate bus choices as well. 
In 2001, NREL, WVU, and WMATA conducted the first phase, a short test program comparing the emissions of WMATA's Cummins Westport, Inc. (CWI) CNG buses and similar Detroit Diesel Corporation (DDC) diesel buses. Table 1 and Figure 1 summarize the vehicle specifications and results. For more information, see the NREL publication, Evaluating the Emission Reduction Benefits of WMATA Natural Gas Buses [1].

Table 1: Vehicles Tested in Phase I of WMATA Emission Testing Program

\begin{tabular}{|l|c|c|}
\hline & CNG Buses & Diesel Buses \\
\hline Manufacturer & New Flyer & Orion \\
\hline Model year & 2001 & 2000 \\
\hline GVWR (Ib) & 40,600 & 42,540 \\
\hline Odometer (mi) & 1,900 & 2,290 \\
& 2,400 & 5,000 \\
& 2,500 & 105,000 \\
& 2,600 & 112,900 \\
\hline Engine & 2,600 & \\
\hline Displacement (L) & CWI C Gas Plus & DDC Series 50 \\
\hline Rated power (hp) & 280 & 8.5 \\
\hline
\end{tabular}

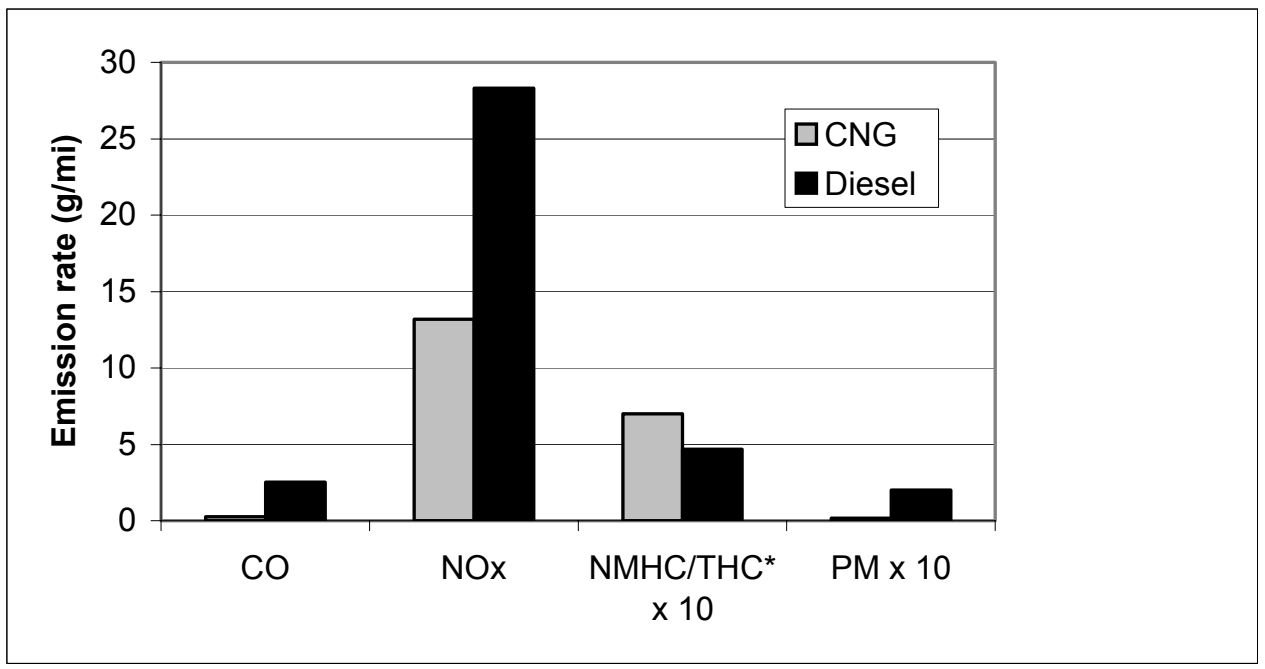

${ }^{*} \mathrm{NMHC}$ for CNG buses, THC for diesel buses.

Figure 1: Results of WMATA Emission Testing Program, Phase I, Central Business District Drive Cycle

This report describes the second phase of the WMATA emission testing program. This phase, completed in 2004, represented a unique opportunity to compare emissions from WMATA's most recent technology CNG and "clean diesel" transit buses. It was designed to evaluate regulated emissions and selected toxic emissions from WMATA's CNG buses with CWI and John Deere engines, diesel buses with DDC engines and catalyzed particulate filters, and newly repowered diesel buses with DDC engines, catalyzed particulate filters, and exhaust gas recirculation (EGR). The following were the specific project objectives:

\footnotetext{
* To obtain this publication, visit the Alternative Fuels Data Center at www.eere.energy.gov/afdc/ or call the National Alternative Fuels Hotline at 1-800-423-1363.
} 
- Demonstrate technologies and methods for controlling exhaust emissions from natural gas engines

- Quantify the levels of regulated and toxic emissions from advanced heavy-duty natural gas and clean diesel transit buses

- Evaluate the emission reduction benefits of recent generation heavy-duty natural gas engine technologies.

\subsection{Test Vehicle Description}

Table 2 describes the vehicles tested in this study. Buses were selected randomly from each category (CWI, John Deere, and DDC). WVU and WMATA coordinated the test schedule; when vehicles were next on the schedule, they were taken out of service and inspected by WMATA mechanics to ensure proper operation. In addition, all three engine manufacturers were given the opportunity to have technicians on site to inspect and prep their vehicles before testing (only John Deere chose to have staff on site for the testing). Table 2 lists the GVWR and curb weight; all buses were tested at a simulated inertia weight representing the empty vehicle curb weight plus one half of the maximum passenger load.

Table 2: Vehicles Tested in Phase II of WMATA Emission Testing Program

\begin{tabular}{|c|c|c|c|c|c|}
\hline \multicolumn{6}{|c|}{ Diesel Buses } \\
\hline & \multicolumn{2}{|c|}{ MY 2000 DDC Series 50} & \multicolumn{3}{|c|}{ MY 2004 DDC Series 50 EGR } \\
\hline Chassis & \multicolumn{2}{|c|}{ MY 2000 Orion Bus Industries Model 06.501} & \multicolumn{3}{|c|}{ MY 1992 Orion Bus Industries Model 06.501} \\
\hline Engine & \multicolumn{2}{|c|}{ MY 2000 DDC Series 50} & \multicolumn{3}{|c|}{ MY 2004 DDC Series 50 EGR } \\
\hline $\begin{array}{l}\text { Engine } \\
\text { Ratings }\end{array}$ & \multicolumn{2}{|c|}{275 hp @ 2,100 rpm } & \multicolumn{3}{|c|}{275 hp @ 2,100 rpm } \\
\hline $\begin{array}{l}\text { EPA NO }_{x} \\
\text { Certification }\end{array}$ & \multicolumn{2}{|c|}{$4.0 \mathrm{~g} / \mathrm{bhp}-\mathrm{hr} \mathrm{NO}_{\mathrm{x}}$} & \multicolumn{3}{|c|}{$2.5 \mathrm{~g} / \mathrm{bhp}-\mathrm{hr} \mathrm{NO}_{\mathrm{x}}+\mathrm{NMHC}$} \\
\hline $\begin{array}{l}\text { After- } \\
\text { treatment }\end{array}$ & \multicolumn{2}{|c|}{ Engelhard DPX ${ }^{\mathrm{TM}}$ catalyzed particulate filter } & \multicolumn{3}{|c|}{$\begin{array}{c}\text { DDC EGR } \\
\text { Engelhard DPX } \\
\text { TM } \text { catalyzed particulate filter }\end{array}$} \\
\hline Transmission & \multicolumn{2}{|c|}{ 5-speed automatic } & \multicolumn{3}{|c|}{ 5-speed automatic } \\
\hline $\begin{array}{l}\text { GVWR/Curb } \\
\text { Weight (Ib) }\end{array}$ & \multicolumn{2}{|c|}{$42,540 / 27,800$} & \multicolumn{3}{|c|}{$39,375-40,600 / 27,325-29,025$} \\
\hline Bus Number & 2073 & 2074 & 9612 & 9633 & 9655 \\
\hline $\begin{array}{l}\text { Odometer } \\
\text { Reading (mi) }\end{array}$ & 159,855 & 145,804 & 395,917 & 568,846 & 482,874 \\
\hline
\end{tabular}




\begin{tabular}{|c|c|c|c|c|c|c|c|}
\hline \multicolumn{8}{|c|}{ CNG Buses } \\
\hline & \multicolumn{4}{|c|}{ CWI C8.3G+ (C Gas Plus) } & \multicolumn{3}{|c|}{ John Deere 6081H } \\
\hline Chassis & \multicolumn{4}{|c|}{ MY 2001 New Flyer C40LF } & \multicolumn{3}{|c|}{ MY 2002 New Flyer C40LF } \\
\hline Engine & \multicolumn{4}{|c|}{ MY 2001 CWI C Gas Plus 280} & \multicolumn{3}{|c|}{ MY 2004 John Deere 6081H } \\
\hline $\begin{array}{l}\text { Engine } \\
\text { Ratings }\end{array}$ & \multicolumn{4}{|c|}{280 hp @ 2,400 rpm } & \multicolumn{3}{|c|}{280 hp @ 2,200 rpm } \\
\hline $\begin{array}{l}\text { EPA NO }_{x} \\
\text { Certification }\end{array}$ & \multicolumn{4}{|c|}{$1.8 \mathrm{~g} / \mathrm{bhp}-\mathrm{hr} \mathrm{NO}_{\mathrm{x}}+\mathrm{NMHC}$} & \multicolumn{3}{|c|}{$1.8 \mathrm{~g} / \mathrm{bhp}-\mathrm{hr} \mathrm{NO}_{\mathrm{x}}+\mathrm{NMHC}$} \\
\hline $\begin{array}{l}\text { After- } \\
\text { treatment }\end{array}$ & \multicolumn{4}{|c|}{ Fleetguard-Nelson oxidation catalyst } & \multicolumn{3}{|c|}{ Johnson Matthey oxidation catalyst } \\
\hline Transmission & \multicolumn{4}{|c|}{ 5-speed automatic } & \multicolumn{3}{|c|}{ 5-speed automatic } \\
\hline $\begin{array}{l}\text { GVWR/Curb } \\
\text { Weight (Ib) }\end{array}$ & \multicolumn{4}{|c|}{$40,600 / 31,800$} & \multicolumn{3}{|c|}{$40,600 / 30,125-31,300$} \\
\hline Bus Number & 2302 & 2304 & 2307 & 2308 & 2460 & 2462 & 2463 \\
\hline $\begin{array}{l}\text { Odometer } \\
\text { Reading (mi) }\end{array}$ & 44,597 & 57,168 & 44,923 & 50,906 & 30,384 & 28,981 & 29,674 \\
\hline
\end{tabular}

Two model year (MY) 2000 Orion Model 06.501 transit buses (Figure 2) were equipped with MY 2000 DDC Series 50 diesel engines and Engelhard DPX catalyzed diesel particulate filters canned by Nelson. The engines were certified to the 1998-2004 EPA standard of $4.0 \mathrm{~g} / \mathrm{bhp}-\mathrm{hr}$ $\mathrm{NO}_{\mathrm{x}}$. The buses were tested at a simulated inertia weight of 32,225 lb.

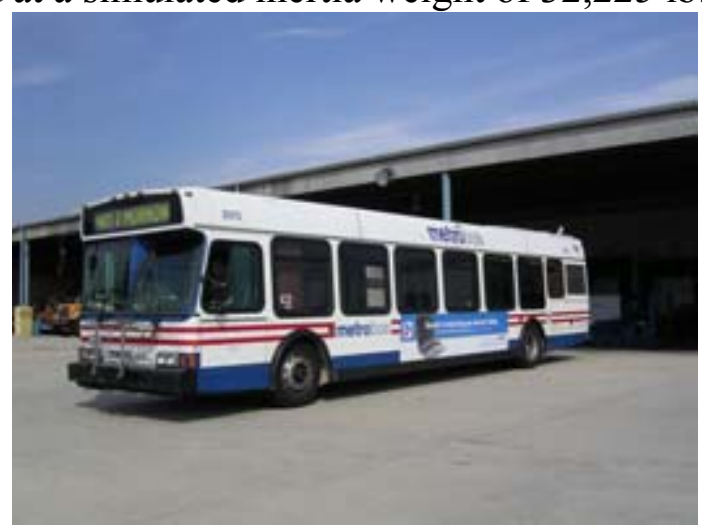

Figure 2: MY 2000 Orion Model 06.501 Bus with MY 2000 DDC Series 50 Diesel Engine

Three MY 1992 Orion Model 06.501 transit buses (Figure 3) were repowered with MY 2004 (post-October 2003) DDC Series 50 engines equipped with EGR and Engelhard DPX catalyzed particulate filters canned by Nelson. The repowers occurred in 2003: bus number 9612 completed $9 / 23 / 2003$ at $490,847 \mathrm{mi} ; 9633$ completed 4/15/2003 at $346,487 \mathrm{mi}$; and 9655 completed 8/14/2003 at 411,531 mi. The engines were certified to the 2004 EPA standard of 2.5 $\mathrm{g} / \mathrm{bhp}-\mathrm{hr} \mathrm{NO}_{\mathrm{x}}+\mathrm{NMHC}$ (non-methane hydrocarbons). The buses were tested at simulated inertia weights of 34,125-34,700 lb. 


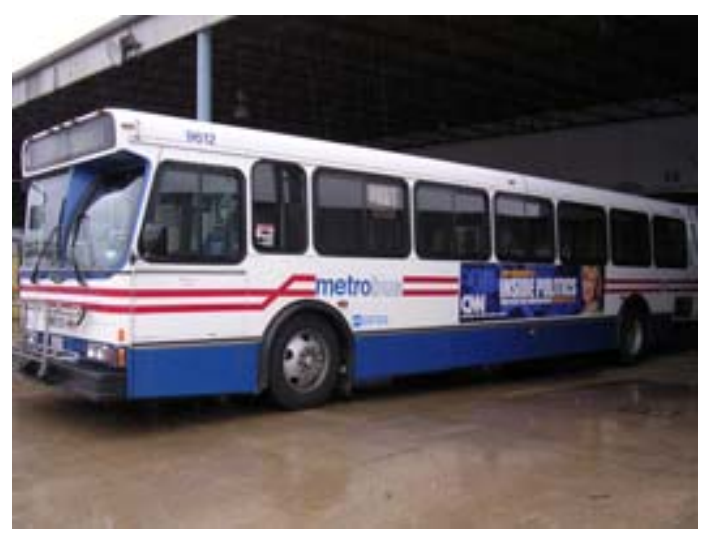

Figure 3: MY 1992 Orion Model 06.501 Bus with MY 2004 DDC Series 50 Engine and EGR

Four MY 2001 New Flyer C40LF transit buses (Figure 4) were equipped with MY 2001 CWI $\mathrm{C} 8.3 \mathrm{G}+(\mathrm{C}$ Gas Plus) CNG-fueled engines. These 8.3 L engines featured lean burn operation and oxidation catalysts to improve emission performance. They were certified to $1.8 \mathrm{~g} / \mathrm{bhp}-\mathrm{hr} \mathrm{NO}_{\mathrm{x}}+$ NMHC. The buses were tested at a simulated inertia weight of 36,450 lb. They have been in revenue service since the summer of 2001.

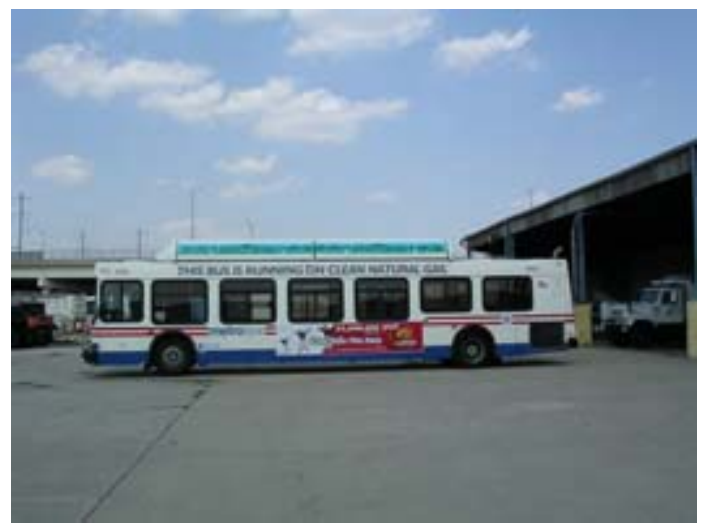

Figure 4: MY 2001 New Flyer C40LF Bus with MY 2001 CWI C Gas Plus CNG Engine

Three MY 2002 New Flyer C40LF transit buses (Figure 5) were equipped with MY 2004 John Deere $6081 \mathrm{H}$ CNG-fueled engines. These 8.1L engines were built in 2001-2002 and updatedsoftware changes only - in 2004, immediately before the emission testing took place; John Deere considers the engines to be MY 2004 and in their field test confirmation stage of development. The engines feature lean burn operation and were equipped with new oxidation catalysts immediately before emission testing to update the engines to a $1.8 \mathrm{~g} / \mathrm{bhp}-\mathrm{hr} \mathrm{NO}_{\mathrm{x}}+\mathrm{NMHC}$ standard. The oxidation catalysts from Johnson Matthey had been "de-greened" through bench operation of 90-120 hours prior to their installation and testing on the dynamometer for this test program. The buses were tested at simulated inertia weights of 34,700-35,875 lb. 


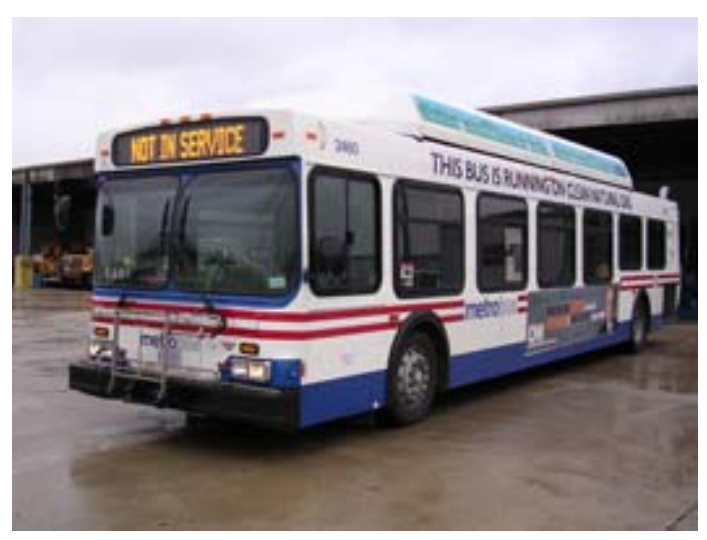

Figure 5: MY 2001 New Flyer C40LF Bus with MY 2004 John Deere 6081H CNG Engine

\subsection{Test Methodology}

The equipment and methods used for this test program consisted of two parts: WVU's TransLab chassis dynamometer and sampling procedures and NREL's toxic emission equipment and sampling procedures.

\subsection{WVU Laboratory Description and Analysis of Emissions}

The WVU TransLab was used to conduct the emissions tests on location at the WMATA facility in Landover, Maryland. Detailed information pertaining to the design and operation of the TransLab can be found in technical papers $[2,3,4]$. The dynamometer unit consisted of power absorbers and a set of selectable flywheels, which allow simulation of tire rolling losses, aerodynamic drag, and inertial load equivalent to a gross vehicle weight of up to $60,000 \mathrm{lb}$. Torque cells and speed transducers continuously measured drive axle torque and speed. Road load drag on the vehicle was mimicked partially by the irreversible (frictional) losses in the laboratory and was adjusted to the correct value at each speed using eddy current power absorbers with closed-loop torque control. A human driver operated the vehicle according to a driving schedule selected to represent the typical duty cycle encountered by the WMATA buses during normal service. Figure 6 shows a bus undergoing emission testing on the dynamometer.

\subsubsection{Analysis of EPA-Regulated Emissions and Fuel Economy}

The emission measurement system used a full-scale dilution tunnel measuring 18 in $(45 \mathrm{~cm})$ in diameter and $20 \mathrm{ft}(6.1 \mathrm{~m})$ in length. The exhaust was mixed with HEPA-filtered ambient air, and the quantity of diluted exhaust was measured precisely by a critical flow venturi system. The diluted exhaust was analyzed using non-dispersive infrared analyzers (NDIR) for carbon monoxide $(\mathrm{CO})$ and carbon dioxide $\left(\mathrm{CO}_{2}\right)$, and using chemiluminescent detection for $\mathrm{NO}_{\mathrm{x}}$. $\mathrm{NO}_{\mathrm{x}}$ emissions were corrected for standard humidity per the Code of Federal Regulations. Hydrocarbons (HC) were analyzed using flame ionization detection (FID). Simultaneous pretunnel bag samples were taken during each test to establish ambient background gas concentrations. The gaseous emissions measurements were performed in accordance with the Code of Federal Regulations Title 40 (CFR40), Part 86, Subpart N [5] to the extent possible. A carbon balance using fuel properties and exhaust emissions data was used to determine fuel economy. 
Particulate matter (PM) was collected using 70-mm fluorocarbon-coated glass fiber filter media, and PM emissions were measured gravimetrically. Dilution tunnel background samples were collected for establishing PM background levels. Even though the tunnel had HEPA-filtered dilution air, PM backgrounds were essential because the dilution tunnel walls may shed particles that are re-entrained into the sample stream or outgas heavy HC that condense onto the PM.

The PM emissions from the vehicles retrofitted with catalyzed particulate filters were expected to be far lower than the emissions from conventional diesel vehicles. To facilitate collection of sufficient PM mass for accurate microbalance measurement, these vehicles were exercised through two back-to-back test cycles such that emissions were collected over a test run that was twice the normal driving distance. The test cycle used for this program was the WMATA cycle. The double-length test cycle was designated as 2WMATA.

Triplicate runs were performed for each emissions test. Additional repeat runs were performed if the coefficient of variation for $\mathrm{CO}_{2}$ and $\mathrm{NO}_{\mathrm{x}}$ emissions exceeded $5 \%$. A minimum of three test runs were averaged for each regulated emissions result reported.

\subsubsection{Analysis of Methane Emissions}

Methane emissions were measured using two identical sample bags collected during the test cycle. Total HC (THC) concentration was measured from one bag using the standard FID measurement and a methane response factor. The methane fraction of the HC was measured from the other bag using gas chromatography; this was achieved with a simplified analytical method and by determining the ratio of the area from the methane peak to the total area of the peaks in the sample. This ratio was multiplied by the THC concentration determined from the first bag, resulting in a value for methane concentration.

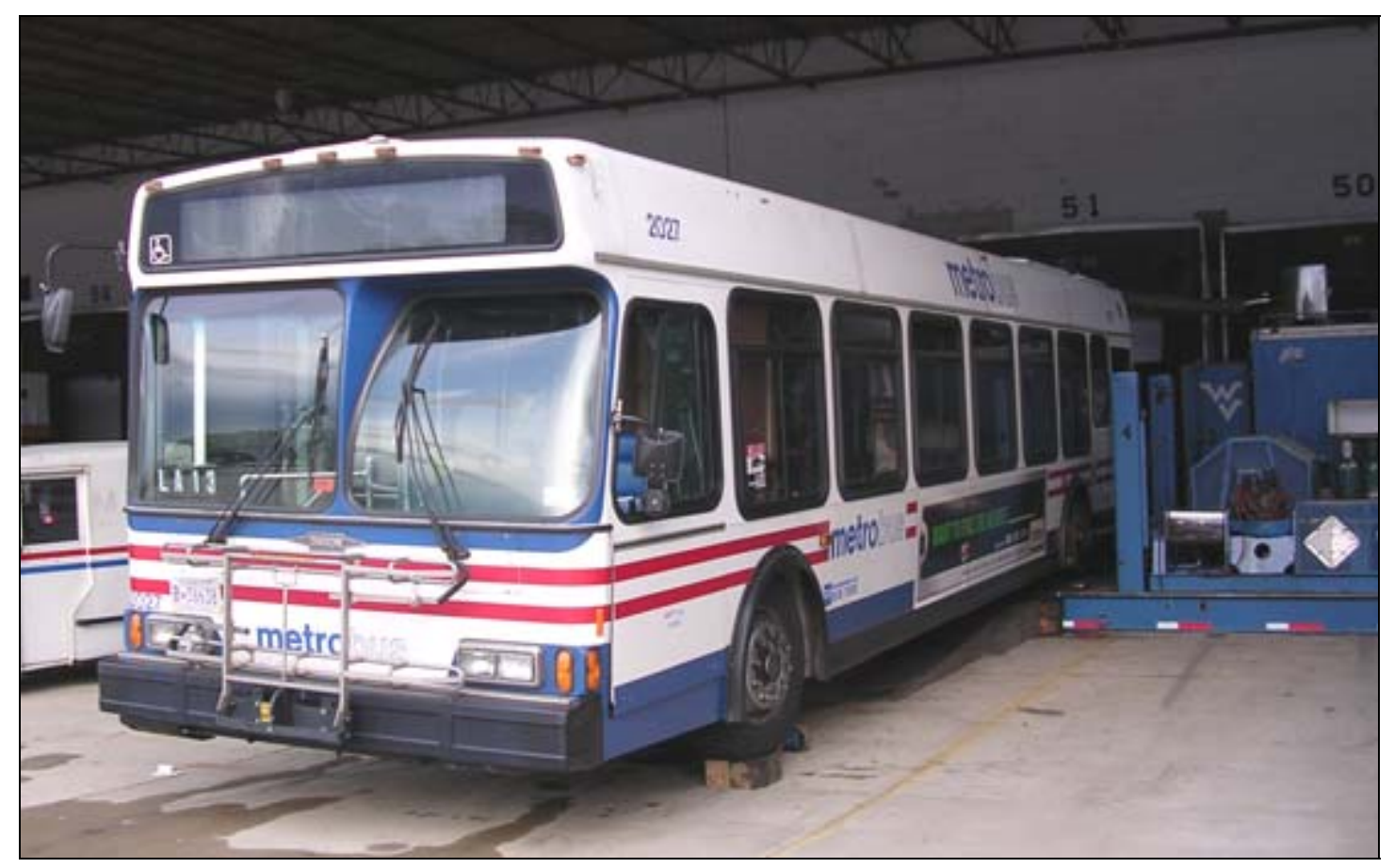

Figure 6: Bus under Test on the WVU TransLab Chassis Dynamometer 


\subsection{NREL Laboratory Description and Analysis of Unregulated Emissions}

The NREL Renewable Fuels and Lubricants (ReFUEL) Laboratory's capabilities to measure unregulated toxic air contaminant emissions consist of a high-performance liquid chromatograph (HPLC). Samples were collected using 2,4-dinitrophenylhydrazine (DNPH) cartridges for subsequent analysis by NREL to determine the levels of carbonyl compounds in the exhaust. DNPH cartridges were acquired from Waters Corp. and stored in a refrigerator until they could be analyzed.

\subsubsection{Analytical Method for Measuring Carbonyls}

Carbonyl (aldehyde and ketone) samples were collected from two separate but identical sample streams, each containing two DNPH cartridges (primary and secondary) in series. The primary and secondary DNPH cartridges were extracted and analyzed separately to determine the concentration of the aldehyde and ketone emissions in the exhaust. Cartridges were eluted with approximately $3 \mathrm{~mL}$ of carbonyl-free HPLC-grade acetonitrile (Burdick and Jackson) to remove all unreacted and derivatized DNPH from the solid phase. The mass of eluent was measured for each cartridge using an analytical balance and was approximately $1.85 \mathrm{~g}$. A volume of $1.5 \mathrm{~mL}$ eluent was transferred to an HPLC autosampler vial and loaded for analysis.

The HPLC analytical method was similar to that developed by the Coordinating Research Council and referred to as the Auto/Oil Method [6]. All analyses were performed in a HewlettPackard Model 1050 HPLC equipped with a quaternary pump and variable wavelength ultraviolet detector. Details of the analytical method are shown in Table 3.

Table 3: HPLC Analytical Method for Carbonyls (Aldehydes and Keton
\begin{tabular}{|l|l|}
\hline Column & Deltabond AK, $(5 \mu \mathrm{m}, 150 \mathrm{~mm} \times 4.6 \mathrm{~mm})$ \\
\hline Column temperature & $40^{\circ} \mathrm{C}$ \\
\hline Injection volume & $10 \mu \mathrm{L}$ \\
\hline Flow rate & $1.5 \mathrm{~mL} / \mathrm{min}$ \\
\hline Solvents & A: Pure acetonitrile \\
& B: $33 \%$ acetonitrile, $67 \%$ water \\
\hline Gradient & $0-10$ min: Hold at $17 \%$ A, 83\% B \\
& $10-15$ min: Ramp to $25 \%$ A, $75 \%$ B \\
& $15-16$ min: Hold at $25 \%$ A, $75 \%$ B \\
& $16-23$ min: Ramp to $55 \%$ A, 45\% B \\
& $23-27$ min: Hold at $55 \%$ A, $45 \%$ B \\
& $27-29$ min: Ramp to $17 \%$ A, 83\% B \\
& $29-32$ min: Hold at $17 \%$ A, $83 \%$ B \\
\hline Detector & Variable wavelength set at $360 \mathrm{~nm}$ \\
\hline
\end{tabular}

The HPLC was calibrated with a prepared standard of 17 DNPH derivatized aldehydes and ketones. The standard was prepared by diluting the EPA TO-11 DNPH mixture (Supelco) from $15 \mu \mathrm{g} / \mathrm{mL}$ down to a final concentration of $240 \mathrm{ng} / \mathrm{mL}$. Additionally, 2-butanone (methyl ethyl ketone) and methacrolein were added to the calibration standard at a concentration of 300 $\mathrm{ng} / \mathrm{mL}$. Sample output of the calibration standard from the HPLC using the method described above is shown in Figure 7. All peaks are resolved with the exception of meta- and para- 
tolualdehyde, which coelute. Also, there is peak overlap between 2-butanone and methacrolein, which is not ideal but not problematic.

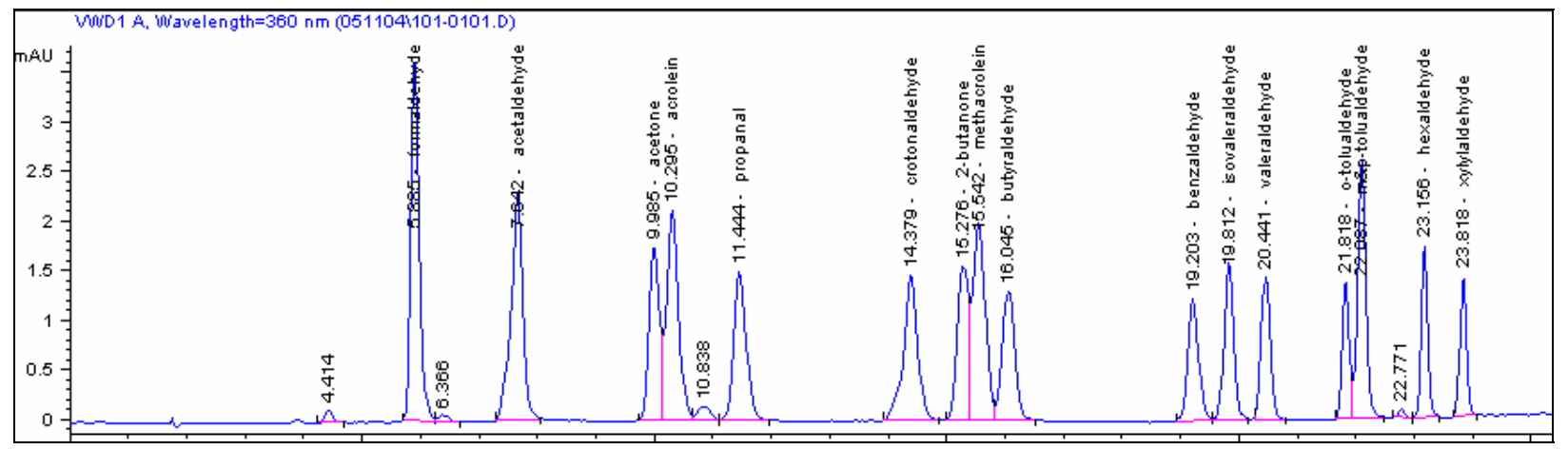

Figure 7: Sample Output from the HPLC for a Calibration Standard Using the Method Defined in Table 3

These concentrations were then converted to mass per unit distance units according to equations in CFR 40, Part 86, Subpart N [5]. The analysis included the following compounds:

- Formaldehyde

- Acetaldehyde

- Acetone

- Acrolein

- Propanal

- Crotonaldehyde

- 2-Butanone

- Methacrolein
- Butyraldehyde

- Benzaldehyde

- Isovaleraldehyde

- Valeraldehyde

- o-Tolualdehyde

- m\&p-Tolualdehyde

- Hexaldehyde

- 2,5-Dimethylbenzaldehyde

\subsubsection{Analytical Method for Hydrocarbons}

Gaseous exhaust samples were also collected and analyzed on site by NREL for 1,3-butadiene and BTEX (benzene, toluene, ethylbenzene, and xylene isomers) using gas chromatography methods. Diluted exhaust samples were collected in $3.2 \mathrm{~L}$ canisters lined with fused silica (Entech Instruments, Part \#29-10322G). The sample was collected from a 90-degree probe located along the center of the dilution tunnel at the sampling plane and conveyed through a nonheated Teflon sample line by an Air Dimensions Mini-Diavac diaphragm pump to the sample canister. A Sierra Sidetrack Model 840L-2-OV1-SV1-E-V1-S1 mass flow controller measured and controlled the sample rate. The sample was filtered through a glass microfiber filter element with a $95 \%$ efficient retention at $0.03 \mu \mathrm{m}$ to remove PM from the sample before it entered the sample canister. After sample collection, the canisters were maintained at $100^{\circ} \mathrm{C}$ to prevent condensation until analysis could be performed. All samples were analyzed within 2 hours of collection.

A metal bellows pump was used to pump gas samples through the injection valve system for the gas chromatograph (GC). The injection valve system included a low-pressure gas regulator (Porter Instruments Co. Model 8310) upstream of an eight-way air-actuated Valco valve. Downstream of the Valco valve was a needle valve for back pressure and a gas flow meter. The sample was pumped at a pressure of $25 \mathrm{psig}$ and a flow rate of approximately $25 \mathrm{~mL} / \mathrm{min}$. Two 
sample loops were connected to the Valco valve (in series when the valve was in "load" position) with volumes of 1 and $5 \mathrm{~mL}$. Sample gas was pumped for approximately 2 minutes prior to injection for GC analysis. After injection, the sample loop was flushed thoroughly with hot helium gas.

The gas was analyzed using a Hewlett-Packard 5890 Series II GC equipped with cryogenic cooling and dual FID. Two identical DB-1 capillary columns (J\&W Scientific, $60 \mathrm{~m} \times 0.32 \mathrm{~mm}$ id $\times 1 \mu \mathrm{m}$ film) were used for the analysis. The only difference in the two columns was the size of the sample injected. The column with the $1 \mathrm{~mL}$ sample was used to resolve $\mathrm{C}_{1}$ to $\mathrm{C}_{3}$ peaks, whereas the column with the $5 \mathrm{~mL}$ sample loop was used for $\mathrm{C}_{4}$ to $\mathrm{C}_{12}$ compounds. Details of the analytical method are shown in Table 4.

Table 4: GC Analytical Method for Hydrocarbons

\begin{tabular}{|l|l|}
\hline Inlet temperature & $220^{\circ} \mathrm{C}$ \\
\hline Carrier & UHP Helium at $1.5 \mathrm{~mL} / \mathrm{min}$ \\
\hline Oven program & $0-3 \mathrm{~min}:$ Hold at $-60^{\circ} \mathrm{C}$ \\
& $3-14 \mathrm{~min}:$ Ramp to $50^{\circ} \mathrm{C}$ at $10^{\circ} \mathrm{C} / \mathrm{min}$ \\
& $14-56.5 \mathrm{~min}:$ Ramp to $220^{\circ} \mathrm{C}$ at $4^{\circ} \mathrm{C} / \mathrm{min}$ \\
& $56.5-59 \mathrm{~min}:$ Hold at $220^{\circ} \mathrm{C}$ \\
\hline Detectors & Dual FID at $280^{\circ} \mathrm{C}$ \\
\hline
\end{tabular}

The GC was calibrated using a 23-component mixture (Scott Specialty Gases, CRC Mix \#4) of HC. The concentration of each compound varies but is approximately 5 ppmC for most compounds. The mixture was loaded into a gas sampling canister, and the same method of sample introduction was used. A sample of the calibration chromatogram from the column with the smaller sampling loop is shown in Figure 8.

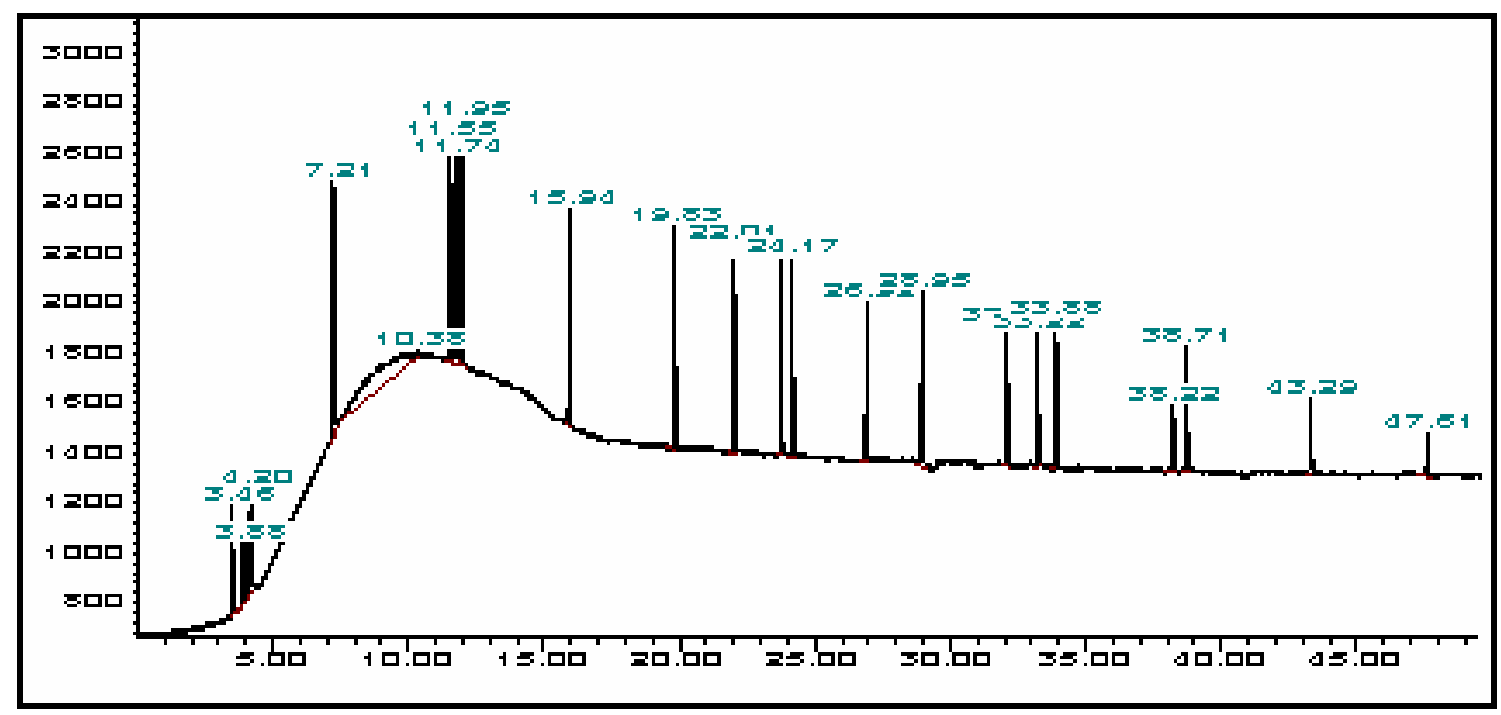

Figure 8: Sample Calibration Chromatogram

After each use, canisters were cleaned with an automated canister cleaning system (Entech Instruments). During the cleaning procedure, up to 6 canisters could be connected to a manifold 
that was in an oven maintained at $100^{\circ} \mathrm{C}$. The cleaning procedure consisted of evacuating the canister to approximately $20 \mathrm{mtorr}$ and holding it at vacuum for $10 \mathrm{~min}$. The canister was then filled with humidified air to a pressure of $20 \mathrm{psig}$ and held for another $10 \mathrm{~min}$. This cycle was repeated three times, and then the canister was finally evacuated to $10 \mathrm{mtorr}$.

\subsection{Test Cycle}

Phase I of the WMATA emission testing used the Central Business District (CBD) driving cycle. For this program, it was determined that the WMATA cycle provided a more real-world duty cycle. The WMATA cycle is a fleet-specific dynamometer driving schedule derived from vehicle speed data logged from transit buses during normal operation in Washington, D.C., and surrounding areas. Vehicle speed data were recorded using a Global Positioning System for multiple routes within the WMATA system. These data constituted a database of vehicle activity, which was analyzed to characterize the duty cycle of a typical WMATA transit bus. The WMATA cycle is shown in Figure 9.

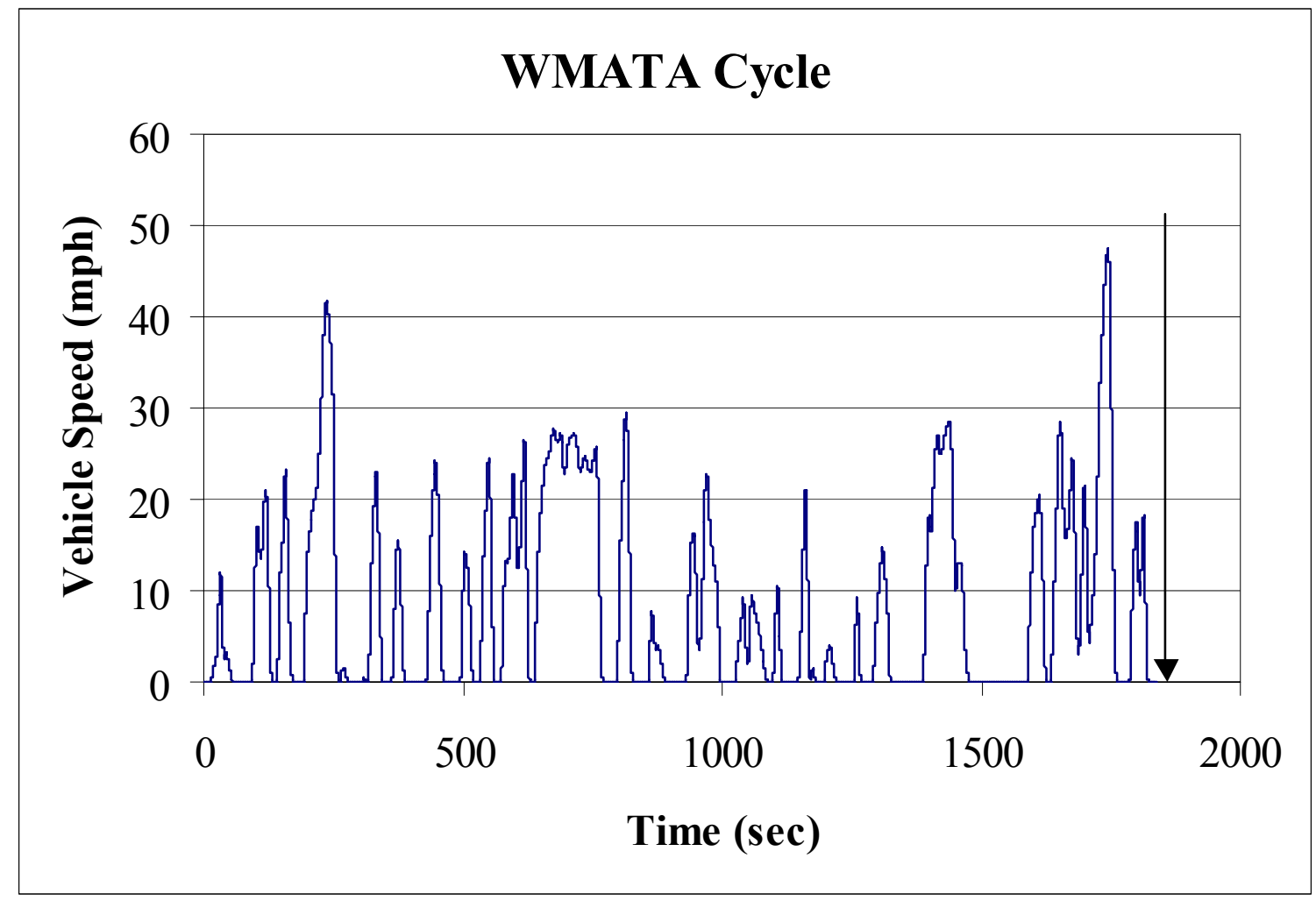

Figure 9: The WMATA Cycle

\subsection{Test Fuels}

At WMATA, natural gas is purchased from Washington Gas, and buses are fueled at WMATA's Bladensburg facility in northeast Washington, D.C. A fuel sample was taken from the first CNG bus as it was installed on the WVU dynamometer. Table 5 shows the results of the natural gas fuel analysis. 
Table 5: WMATA Compressed Natural Gas Properties, April 2004

\section{Gas Analytical Services, Inc.}

P.O. Box 1028

Bridgeport, WV 26330-0461

Phone: (304) 623-0020

FAX: (304) 624-8065

\section{FRACTIONAL ANALYSIS}

\begin{tabular}{|llll|}
\hline Customer: & West Virginia University - MAE Department & Sample Date: & $04 / 07 / 2004$ \\
Field: & Morgantown, WV & Sample Time: & $00: 00$ \\
Analysis \#: & 27091 & Collected By: & B. Rapp \\
Station: & WMATA Bus 2302 & Effective Date: & $04 / 07 / 2004$ \\
Meter: & & Sample Pressure & 2200.00PSIG \\
\hline
\end{tabular}

\begin{tabular}{|l|r|r|}
\hline \multicolumn{1}{|c|}{ Component } & MOL \% & \multicolumn{1}{|c|}{ GPM } \\
\hline Methane & 94.291 & \\
\hline Ethane & 3.624 & 0.97 \\
\hline Propane & 0.627 & 0.17 \\
\hline I-Butane & 0.101 & 0.03 \\
\hline N-Butane & 0.112 & 0.04 \\
\hline I-Pentane & 0.023 & 0.01 \\
\hline N-Pentane & 0.018 & 0.01 \\
\hline Nitrogen & 0.558 & \\
\hline CO2 & 0.564 & \\
\hline Oxygen & 0.003 & \\
\hline Hexanes+ & 0.079 & \\
\hline & & \\
\hline & & \\
\hline & & \\
\hline & & \\
\hline & & \\
\hline & & \\
\hline & & \\
\hline & & \\
\hline & & \\
\hline
\end{tabular}

Analytical Results at Base Conditions

\begin{tabular}{lr} 
BTU/SCF (Dry): & 1049.599 \\
BTU/SCF (Saturated): & 1032.256 \\
PSIA: & 14.730 \\
Temperature $\left({ }^{\circ}\right.$ F): & 60.000 \\
Z Factor (Dry): & 0.99777 \\
Z Factor (Saturated): & 0.99773 \\
\hline
\end{tabular}

\begin{tabular}{|lr|}
\hline \multicolumn{2}{|c|}{ Analytical Results at Contract Conditions } \\
\hline BTU/SCF (Dry): & 1049.599 \\
BTU/SCF (Saturated): & 1032.256 \\
PSIA: & 14.730 \\
Temperature $\left({ }^{\circ} \mathrm{F}\right):$ & 60.000 \\
Z Factor (Dry): & 0.99777 \\
Z Factor (Saturated): & 0.99773 \\
\hline
\end{tabular}

\begin{tabular}{|lc|}
\hline \multicolumn{2}{|c|}{ Calculated Specific Gravities } \\
\hline Ideal Gravity: & 0.5913 \\
Real Gravity: & 0.5924 \\
\hline
\end{tabular}

Gross Heating Values are Based on GPA 2145-91. Compressibility is Calculated using AGA-8.

Diesel buses at WMATA are fueled with low-sulfur diesel fuel purchased from Tosco. There are several locations for refueling in the city, and all are supplied with the same contract fuel. A fuel sample was taken from the first diesel bus as it was installed on the WVU dynamometer. Table 6 shows the results of the diesel fuel analysis.

\subsection{Results and Discussion}

Emission data are summarized in Table 7. Bus number 2307 (CNG with CWI G Gas Plus engine) exhibited extremely high $\mathrm{CO}$ emissions compared with the other buses in the group. The anomalous $\mathrm{CO}$ result may indicate a malfunction or maintenance problem. Although results from bus 2307 are included in Table 7 and subsequent emissions results figures and tables, they are excluded from the average emissions results for this group discussed in the text. 
Table 6: WMATA Diesel Properties, June 2004

\begin{tabular}{|c|c|c|}
\hline Test Parameter & Test Method & WMATA BUS 9655 \\
\hline $\begin{array}{l}\text { Density, } g / m L \\
\text { API }\end{array}$ & ASTM D4052 & $\begin{array}{c}0.8300 \\
38.9\end{array}$ \\
\hline Kinematic Viscosity, $40^{\circ} \mathrm{C}, \mathrm{cSt}$ & ASTM D445 & 1.773 \\
\hline Flash Point $\left({ }^{\circ} \mathrm{C}\right)$ & ASTM D93 & 68.9 \\
\hline Pour Point $\left({ }^{\circ} \mathrm{C}\right)$ & ASTM D97 & -48 \\
\hline Sulfur (ppm) & ASTM D5453 & 17.9 \\
\hline $\begin{array}{c}\text { Distillation }\left({ }^{\circ} \mathrm{C}\right) \\
\text { IBP } \\
10 \% \\
50 \% \\
90 \% \\
\text { FBP } \\
\text { Recovery (vol\%) } \\
\text { Loss (vol\%) } \\
\text { Residue (vol\%) }\end{array}$ & ASTM D86 & $\begin{array}{c}179.1 \\
202.8 \\
225.9 \\
254.0 \\
275.0 \\
99.1 \\
0.5 \\
0.5\end{array}$ \\
\hline Ash (mass \%) & ASTM D482 & $<0.001$ \\
\hline $\begin{array}{l}\text { Gross Heat of Combustion (BTU/lb) } \\
\text { Net Heat of Combustion (BTU//b) }\end{array}$ & ASTM D240 & $\begin{array}{l}19675.4 \\
18447.4 \\
\end{array}$ \\
\hline $\begin{array}{c}\text { Carbon (mass \%) } \\
\text { Hydrogen (mass \%) } \\
\text { Oxygen (mass \% by difference) }\end{array}$ & ASTM D5291 & $\begin{array}{l}86.19 \\
13.46 \\
<0.10\end{array}$ \\
\hline Cloud Point $\left({ }^{\circ} \mathrm{C}\right)$ & ASTM D2500 & -46 \\
\hline $\begin{array}{c}\text { SFC Aromatics (mass \%) } \\
\text { Monoaromatics } \\
\text { PNA }\end{array}$ & ASTM D5186 & $\begin{array}{c}18.3 \\
3.4 \\
216\end{array}$ \\
\hline $\begin{array}{c}\text { Hydrocarbon Types (vol \%) } \\
\text { Aromatics } \\
\text { Olefins } \\
\text { Saturates } \\
\end{array}$ & ASTM D1319 & $\begin{array}{c}19.7 \\
1.1 \\
79.2\end{array}$ \\
\hline Gum Content $(\mathrm{mg} / 100 \mathrm{~mL})$ & ASTM D381 & 1.8 \\
\hline Cetane Number & ASTM D613 & 45 \\
\hline Water and Sediment & ASTM D2709 & 0.01 \\
\hline Copper Corrosion & ASTM D130 & $1 \mathrm{~A}$ \\
\hline Carbon Residue (mass \%) & ASTM D524 & 0.05 \\
\hline
\end{tabular}

API—American Petroleum Institute; cSt—centiStokes; FBP—-final boiling point; IBP—initial boiling point; PNA— polynuclear aromatics; SFC — supercritical fluid chromatography.

\subsection{Oxides of Nitrogen}

Figure 10 shows $\mathrm{NO}_{\mathrm{x}}$ emissions. The $\mathrm{x}$-axis labels indicate engine model, fuel type, aftertreatment device, and vehicle ID number. Each $\mathrm{NO}_{\mathrm{x}}$ result represents the average of three test runs. Each nitrogen oxide (NO) result is the average of two test runs. The error bars show the maximum and minimum individual test run values. The error bars do not indicate the standard deviation, confidence interval, or other statistically derived quantification of error. Chassis dynamometer emission results are given in units of $\mathrm{g} / \mathrm{mi}$; these results cannot be compared directly with emission standards (e.g., EPA standards) derived from engine dynamometer testing, which have units of $\mathrm{g} / \mathrm{bhp}-\mathrm{hr}$. 
Table 7: Summary of Emission Results

\begin{tabular}{|c|c|c|c|c|c|c|c|c|c|c|c|c|c|}
\hline $\begin{array}{c}\text { Vehicle } \\
\text { Configuration }\end{array}$ & $\begin{array}{l}\text { Vehicle } \\
\text { Number }\end{array}$ & $\begin{array}{l}\text { Test } \\
\text { ID }\end{array}$ & $\begin{array}{c}\text { Run } \\
\text { ID }\end{array}$ & $\begin{array}{c}\mathrm{CO} \\
(\mathrm{g} / \mathrm{mi})\end{array}$ & $\begin{array}{c}\mathrm{NO}_{\mathrm{x}} \\
(\mathrm{g} / \mathrm{mi})\end{array}$ & $\begin{array}{c}\mathrm{NO} \\
(\mathrm{g} / \mathrm{mi})\end{array}$ & $\begin{array}{c}\mathrm{CH}_{4} \\
(\mathrm{~g} / \mathrm{mi})\end{array}$ & $\begin{array}{c}\text { NMHC* } \\
(\mathrm{g} / \mathrm{mi})\end{array}$ & $\begin{array}{c}P M \\
(\mathrm{~g} / \mathrm{mi})\end{array}$ & $\begin{array}{c}\mathrm{CO}_{2} \\
(\mathrm{~g} / \mathrm{mi})\end{array}$ & Miles & mpeg & BTU/mile \\
\hline \multirow{10}{*}{$\begin{array}{c}\text { MY } 2000 \\
\text { DDC Series } \\
50 \\
\text { with } \\
\text { DPX }\end{array}$} & \multicolumn{13}{|c|}{ Diesel Buses with MY 2000 DDC Series 50 Engines } \\
\hline & \multirow{4}{*}{2073} & \multirow{3}{*}{4166} & 1 & 0.27 & 26.1 & & & BDL & 0.016 & 3,266 & 4.25 & 2.96 & 43,267 \\
\hline & & & 2 & 0.25 & 25.8 & 18.9 & & BDL & 0.013 & 3,232 & 4.26 & 2.99 & 42,805 \\
\hline & & & 3 & 0.18 & 24.9 & 17.6 & & BDL & 0.011 & 3,229 & 4.24 & 2.99 & 42,765 \\
\hline & & \multicolumn{2}{|c|}{ Average } & 0.23 & 25.6 & 18.2 & & BDL & 0.013 & 3,242 & 4.24 & 2.98 & 42,946 \\
\hline & \multirow{4}{*}{2074} & \multirow{3}{*}{4169} & 1 & 0.04 & 24.1 & & & 0.002 & 0.007 & 3,087 & 4.22 & 3.13 & 40,896 \\
\hline & & & 2 & 0.33 & 23.9 & 18.1 & & $\mathrm{BDL}$ & 0.005 & 3,067 & 4.22 & 3.15 & 40,632 \\
\hline & & & 4 & 0.11 & 23.1 & 17.7 & & $\mathrm{BDL}$ & 0.012 & 3,074 & 4.22 & 3.14 & 40,725 \\
\hline & & \multicolumn{2}{|c|}{ Average } & 0.16 & 23.7 & 17.9 & & 0.002 & 0.008 & 3,076 & 4.22 & 3.14 & 40,751 \\
\hline & \multicolumn{3}{|c|}{2000 DDC S50 Average } & 0.19 & 24.6 & 17.7 & & 0.002 & 0.010 & 3,159 & 4.23 & 3.06 & 41,848 \\
\hline \multirow{14}{*}{$\begin{array}{c}\text { MY } 2004 \\
\text { DDC Series } \\
50 \\
\text { with } \\
\text { EGR \& DPX }\end{array}$} & \multicolumn{13}{|c|}{ Diesel Buses with MY 2004 DDC Series 50 Engines } \\
\hline & \multirow{4}{*}{9612} & \multirow{3}{*}{4151} & 1 & 0.27 & 18.3 & & & $\mathrm{BDL}$ & 0.011 & 3,472 & 4.19 & 2.78 & 45,988 \\
\hline & & & 3 & 0.44 & 17.9 & 13.1 & & BDL & 0.007 & 3,430 & 4.25 & 2.82 & 45,432 \\
\hline & & & 4 & 0.33 & 17.5 & 12.2 & & 0.0028 & 0.013 & 3,424 & 4.23 & 2.82 & 45,354 \\
\hline & & \multicolumn{2}{|c|}{ Average } & 0.34 & 17.9 & 12.6 & & 0.003 & 0.010 & 3,442 & 4.22 & 2.81 & 45,591 \\
\hline & \multirow{4}{*}{9633} & \multirow{3}{*}{4163} & 1 & 0.29 & 17.4 & & & $\mathrm{BDL}$ & 0.046 & 3,298 & 4.24 & 2.93 & 43,684 \\
\hline & & & 2 & 0.23 & 16.9 & 8.7 & & $\mathrm{BDL}$ & 0.042 & 3,278 & 4.26 & 2.95 & 43,427 \\
\hline & & & 3 & 0.19 & 17.6 & 9.3 & & BDL & 0.054 & 3,308 & 4.25 & 2.92 & 43,824 \\
\hline & & \multicolumn{2}{|c|}{ Average } & 0.24 & 17.3 & 9.0 & & BDL & 0.047 & 3,295 & 4.25 & 2.93 & 43,645 \\
\hline & \multirow{4}{*}{9655} & \multirow{3}{*}{4148} & 1 & 0.34 & 18.3 & & & BDL & 0.020 & 3,299 & 4.22 & 2.93 & 43,703 \\
\hline & & & 2 & 0.54 & 18.1 & 12.9 & & $\mathrm{BDL}$ & 0.017 & 3,296 & 4.21 & 2.93 & 43,662 \\
\hline & & & 3 & 0.41 & 18.7 & 13.5 & & BDL & 0.021 & 3,312 & 4.22 & 2.92 & 43,872 \\
\hline & & \multicolumn{2}{|c|}{ Average } & 0.43 & 18.4 & 13.2 & & BDL & 0.019 & 3,302 & 4.21 & 2.92 & 43,746 \\
\hline & \multicolumn{3}{|c|}{2004 DDC S50 Average } & 0.34 & 17.9 & 11.6 & & 0.003 & 0.025 & 3,346 & 4.23 & 2.89 & 44,327 \\
\hline & & & & & & Buse & with MY & $001 \mathrm{CWI}$ & ias Plu & ngines & & & \\
\hline & & & 1 & 0.68 & 18.5 & & 14.2 & 0.95 & $\mathrm{BDL}$ & 2,115 & 4.23 & 3.19 & 40,069 \\
\hline & & 4142 & 2 & 0.49 & 17.5 & 14.7 & 13.9 & 0.94 & $\mathrm{BDL}$ & 2,063 & 4.28 & 3.27 & 39,079 \\
\hline & 2302 & & 3 & 0.48 & 17.6 & 14.6 & 13.9 & 1.15 & $\mathrm{BDL}$ & 2,087 & 4.26 & 3.23 & 39,535 \\
\hline & & Av & & 0.55 & 17.9 & 14.6 & 14.0 & 1.01 & BDL & 2,088 & 4.26 & 3.23 & 39,561 \\
\hline & & & 2 & 0.26 & 17.0 & & 15.6 & 1.11 & 0.011 & 1,209 & 4.26 & 3.19 & 40,033 \\
\hline MY 2001 CWI & 2304 & 4139 & 3 & 0.50 & 17.3 & 14.2 & 16.0 & 1.12 & 0.006 & 2,127 & 4.25 & 3.17 & 40,390 \\
\hline C8.3G+ CNG & 2304 & & 4 & 0.37 & 17.8 & 14.4 & 16.1 & 1.13 & 0.005 & 2,092 & 4.24 & 3.22 & 39,749 \\
\hline with & & $\mathbf{A v}$ & & 0.38 & 17.4 & 14.3 & 15.9 & 1.12 & 0.008 & 2,110 & 4.25 & 3.19 & 40,058 \\
\hline oxidation & & & 1 & 10.53 & 25.3 & & 15.2 & 0.92 & 0.010 & 2,157 & 4.23 & 3.10 & 41,195 \\
\hline catalyst & & 4145 & 2 & 8.61 & 24.5 & 21.8 & 16.9 & 1.05 & 0.009 & 2,145 & 4.23 & 3.12 & 41,004 \\
\hline & 2307 & & 3 & 7.37 & 23.5 & 20.7 & 17.5 & 1.05 & 0.006 & 2,111 & 4.22 & 3.17 & 40,372 \\
\hline & & $\overline{A v}$ & & 8.84 & 24.4 & 21.2 & 16.5 & 1.01 & 0.008 & 2,138 & 4.22 & 3.13 & 40,857 \\
\hline & & 1198 & 1 & 0.77 & 21.7 & & 21.8 & 1.18 & 0.025 & 2,585 & 4.22 & 2.60 & 49,207 \\
\hline & 2308 & 4198 & 2 & 0.70 & 22.0 & 18.1 & 22.2 & 1.19 & 0.021 & 2,566 & 4.22 & 2.62 & 48,868 \\
\hline & & Av & & 0.73 & 21.8 & 18.1 & 22.0 & 1.18 & 0.023 & 2,575 & 4.22 & 2.61 & 49,038 \\
\hline & & Averac & & 2.63 & 20.4 & 17.1 & 17.1 & 1.08 & 0.009 & 2,228 & 4.24 & 3.04 & 42,378 \\
\hline & CWI Ave & age w/o & 2307 & 0.55 & 19.0 & 15.7 & 17.3 & 1.10 & 0.010 & 2,258 & 4.24 & 3.01 & 42,886 \\
\hline
\end{tabular}

${ }^{*} \mathrm{THC}$ for the diesel buses. 
Table 7 (continued)

\begin{tabular}{|c|c|c|c|c|c|c|c|c|c|c|c|c|c|}
\hline $\begin{array}{c}\text { Vehicle } \\
\text { Configuration }\end{array}$ & $\begin{array}{l}\text { Vehicle } \\
\text { Number }\end{array}$ & $\begin{array}{c}\text { Test } \\
\text { ID }\end{array}$ & $\begin{array}{l}\text { Run } \\
\text { ID }\end{array}$ & $\begin{array}{c}\mathrm{CO} \\
(\mathrm{g} / \mathrm{mi})\end{array}$ & $\begin{array}{l}\mathrm{NO}_{\mathrm{x}} \\
(\mathrm{g} / \mathrm{mi})\end{array}$ & $\begin{array}{c}\mathrm{NO} \\
(\mathrm{g} / \mathrm{mi})\end{array}$ & $\underset{(\mathrm{g} / \mathrm{mi})}{\mathrm{CH}_{4}}$ & $\begin{array}{c}\mathrm{NMHC}^{*} \\
(\mathrm{~g} / \mathrm{mi})\end{array}$ & $\begin{array}{c}\mathrm{PM} \\
(\mathrm{g} / \mathrm{mi})\end{array}$ & $\begin{array}{c}\mathrm{CO}_{2} \\
(\mathrm{~g} / \mathrm{mi})\end{array}$ & Miles & mpeg & BTU/mile \\
\hline \multirow{14}{*}{$\begin{array}{c}\text { MY } 2004 \text { John } \\
\text { Deere } 6081 \mathrm{H} \\
\text { CNG } \\
\text { with } \\
\text { oxidation } \\
\text { catalyst }\end{array}$} & \multicolumn{13}{|c|}{ CNG Buses with MY 2004 John Deere 6081H Engines } \\
\hline & \multirow{4}{*}{2460} & \multirow{3}{*}{4154} & 1 & 0.27 & 5.7 & & 9.51 & 0.43 & 0.003 & 1,907 & 4.22 & 3.56 & 35,920 \\
\hline & & & 2 & 0.06 & 5.7 & 4.7 & N/A & N/A & 0.004 & 1,914 & 4.23 & 3.55 & 36,052 \\
\hline & & & 3 & 0.27 & 6.1 & 5.0 & 9.51 & 0.91 & 0.002 & 1,919 & 4.23 & 3.54 & 36,165 \\
\hline & & \multicolumn{2}{|c|}{ Average } & 0.20 & 5.82 & 4.8 & 9.51 & 0.67 & 0.003 & 1,913 & 4.23 & 3.55 & 36,046 \\
\hline & \multirow{4}{*}{2462} & \multirow{3}{*}{4160} & 1 & $\mathrm{BDL}$ & 11.6 & & 10.2 & 0.48 & 0.003 & 2,375 & 4.23 & 2.87 & 44,626 \\
\hline & & & 2 & 0.16 & 11.4 & 9.4 & 10.6 & 0.51 & 0.003 & 2,343 & 4.23 & 2.90 & 44,063 \\
\hline & & & 3 & 0.12 & 11.5 & 9.6 & 10.6 & 0.42 & 0.006 & 2,357 & 4.22 & 2.89 & 44,330 \\
\hline & & \multicolumn{2}{|c|}{ Average } & 0.09 & 11.5 & 9.5 & 10.5 & 0.47 & 0.004 & 2,358 & 4.23 & 2.88 & 44,330 \\
\hline & \multirow{4}{*}{2463} & \multirow{3}{*}{4157} & 2 & 0.14 & 10.3 & 8.9 & 11.0 & 0.62 & 0.004 & 2,245 & 4.23 & 3.03 & 42,274 \\
\hline & & & 3 & 0.14 & 10.1 & 8.6 & 12.7 & N/A & 0.006 & 2,233 & 4.24 & 3.04 & 42,087 \\
\hline & & & 5 & 0.12 & 9.4 & & 11,5 & 0.42 & 0.008 & 2,262 & 4.24 & 3.00 & 42,608 \\
\hline & & \multicolumn{2}{|c|}{ Average } & 0.13 & 9.92 & 8.7 & 11.8 & 0.52 & 0.006 & 2,247 & 4.24 & 3.02 & 42,323 \\
\hline & \multicolumn{3}{|c|}{ John Deere Average } & 0.14 & 9.08 & 7.7 & 10.6 & 0.55 & 0.004 & 2,173 & 4.23 & 3.15 & 40,899 \\
\hline
\end{tabular}

${ }^{*} \mathrm{THC}$ for the diesel buses. 
Two chemiluminescent $\mathrm{NO}_{\mathrm{x}}$ analyzers were used to estimate the $\mathrm{NO}$ and $\mathrm{NO}_{2}$ split. These analyzers shared a common probe in the dilution tunnel and could operate in either $\mathrm{NO}_{\mathrm{x}} \mathrm{NO}+$ $\mathrm{NO}_{2}$ ) or $\mathrm{NO}$ mode. During the first test run of each series, both analyzers were set in $\mathrm{NO}_{\mathrm{x}}$ mode to verify satisfactory agreement between the two analyzers; therefore, there is not an NO result for the first run of each series. In subsequent runs, one analyzer was set in the $\mathrm{NO}_{\mathrm{x}}$ mode, and the other was set to the NO mode. This approach made it simple and convenient to study emissions trends from diesel buses equipped with catalyzed particulate filters and natural gas buses equipped with oxidation catalysts. Emissions from vehicles equipped with catalyzed particulate filters and other aftertreatment devices may produce $30 \%-40 \%$ of the $\mathrm{NO}_{\mathrm{x}}$ as $\mathrm{NO}_{2}$. In these cases, it is possible to gather information on $\mathrm{NO} / \mathrm{NO}_{2}$ fractions from the $\mathrm{NO}_{\mathrm{x}}$ and $\mathrm{NO}$ measurements with an expected accuracy of approximately plus or minus $10 \%$.

The John Deere CNG buses averaged $9.08 \mathrm{~g} / \mathrm{mi} \mathrm{NO}_{\mathrm{x}}$, with a high of $11.5 \mathrm{~g} / \mathrm{mi}$ and a low of 5.82 $\mathrm{g} / \mathrm{mi}$. NO constituted $82 \%-88 \%$ of total $\mathrm{NO}_{\mathrm{x}}$ emissions.

The MY 2004 DDC diesel buses with EGR and DPX particulate filters averaged $17.9 \mathrm{~g} / \mathrm{mi} \mathrm{NO}_{\mathrm{x}}$, with a high of $18.4 \mathrm{~g} / \mathrm{mi}$ and a low of $17.3 \mathrm{~g} / \mathrm{mi}$; $\mathrm{NO}_{\mathrm{x}}$ emissions were highly consistent among the test buses. $\mathrm{NO}$ constituted $52 \%-72 \%$ of total $\mathrm{NO}_{\mathrm{x}}$ emissions.

The CWI CNG buses averaged $19.0 \mathrm{~g} / \mathrm{mi} \mathrm{NO}_{\mathrm{x}}$, with a high of $21.8 \mathrm{~g} / \mathrm{mi}$ and a low of $17.4 \mathrm{~g} / \mathrm{mi}$. $\mathrm{NO}$ constituted approximately $82 \%$ of total $\mathrm{NO}_{\mathrm{x}}$ emissions.

The MY 2000 DDC diesel buses with DPX particulate filters averaged $24.6 \mathrm{~g} / \mathrm{mi} \mathrm{NO}_{\mathrm{x}}$, with a high of $25.6 \mathrm{~g} / \mathrm{mi}$ and a low of $23.7 \mathrm{~g} / \mathrm{mi}$. NO constituted approximately $72 \%$ of total $\mathrm{NO}_{\mathrm{x}}$ emissions.

\subsection{Particulate Matter}

Figure 11 shows PM emissions. Each PM result represents the average of three test runs. The error bars show the maximum and minimum individual test run values. PM emissions from all of the buses were very low-less than $0.05 \mathrm{~g} / \mathrm{mi}$.

The John Deere CNG buses averaged $0.004 \mathrm{~g} / \mathrm{mi}$ PM, with a high of $0.006 \mathrm{~g} / \mathrm{mi}$ and a low of $0.003 \mathrm{~g} / \mathrm{mi}$.

The MY 2004 DDC diesel buses with EGR and DPX particulate filters averaged $0.025 \mathrm{~g} / \mathrm{mi} \mathrm{PM}$, with a low of $0.01 \mathrm{~g} / \mathrm{mi}$ and a high of $0.047 \mathrm{~g} / \mathrm{mi}$.

The CWI CNG buses averaged $0.010 \mathrm{~g} / \mathrm{mi}$ PM, with a high of $0.023 \mathrm{~g} / \mathrm{mi}$; PM emissions from bus number 2302 were below the detectable limit of the laboratory and measurement techniques employed.

The MY 2000 DDC diesel buses with DPX particulate filters averaged $0.010 \mathrm{~g} / \mathrm{mi}$ PM, with a high of $0.013 \mathrm{~g} / \mathrm{mi}$ and a low of $0.008 \mathrm{~g} / \mathrm{mi}$. 


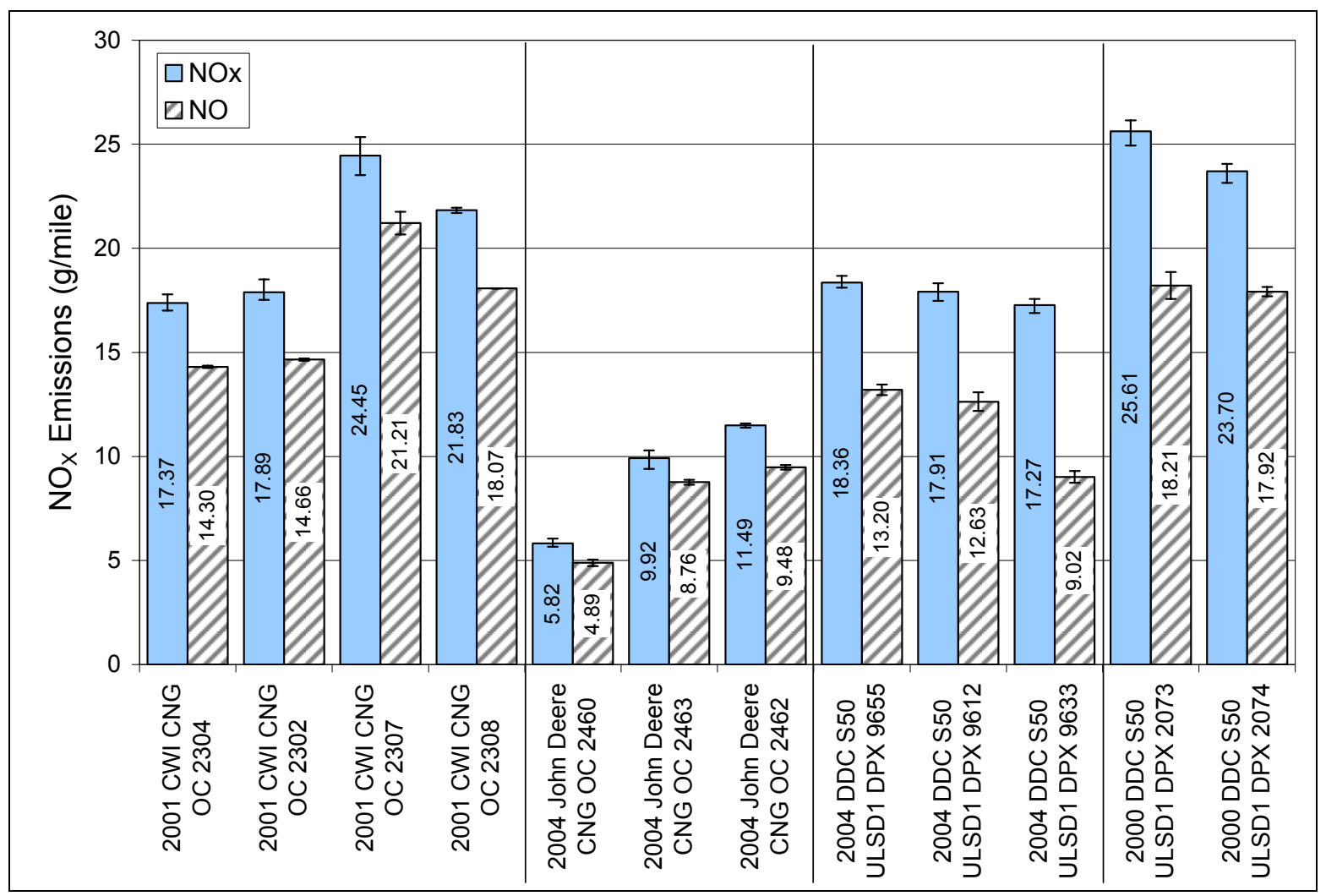

Figure 10: $\mathrm{NO}_{\mathrm{x}}$ Emissions

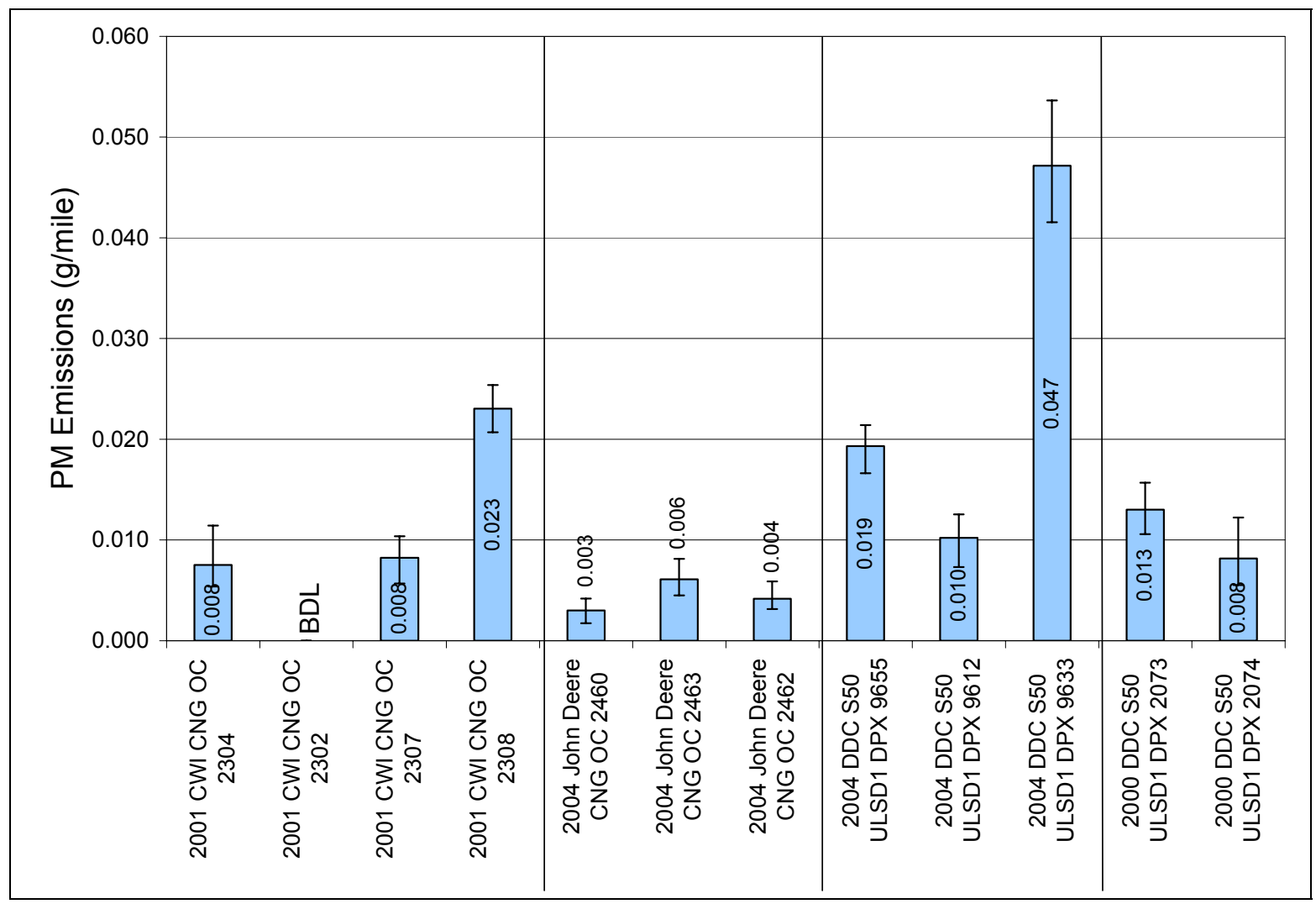

Figure 11: PM Emissions 


\subsection{Carbon Monoxide}

Figure 12 shows $\mathrm{CO}$ emissions. $\mathrm{CO}$ emissions were extremely low for all vehicle technologies tested with the exception of one anomalously high result from CWI CNG bus 2307. Although $\mathrm{CO}$ emissions are not considered to be a great challenge in meeting future emission regulations, this result may prompt a closer look at the durability of specific oxidation catalysts. See Section 7.1 below for further discussion of $\mathrm{CO}$ results.

The John Deere CNG buses averaged $0.14 \mathrm{~g} / \mathrm{mi}$ CO. The MY 2004 DDC diesel buses averaged $0.34 \mathrm{~g} / \mathrm{mi}$ CO. The CWI CNG buses averaged $0.55 \mathrm{~g} / \mathrm{mi}$ CO. The MY 2000 DDC diesel buses averaged $0.19 \mathrm{~g} / \mathrm{mi} \mathrm{CO}$.

\subsection{Hydrocarbons}

Figure 13 shows HC emissions. THC emissions are shown for the diesel buses, whereas only NMHC are plotted for the CNG buses. For the diesel buses, THC emissions were below the detection limit for most test runs, most likely owing to the use of catalyzed particulate filters. The CWI CNG buses averaged $1.10 \mathrm{~g} / \mathrm{mi}$ NMHC, and the John Deere CNG buses averaged 0.55 $\mathrm{g} / \mathrm{mi} \mathrm{NMHC}$.

Figure 14 shows methane $\left(\mathrm{CH}_{4}\right)$ emissions for the $\mathrm{CNG}$ buses. Methane is not an ozone precursor and is, therefore, not regulated by the EPA or California Air Resources Board (CARB). For regulatory purposes, only the NMHC emissions from natural gas vehicles are considered. Figure 14 shows two methane values for each vehicle, one from WVU measurements and one from NREL measurements; the measurement methods are described in sections 4.1.2 (WVU) and 4.2.2 (NREL) above. Using the WVU method, methane emissions from the CWI CNG buses averaged $17.3 \mathrm{~g} / \mathrm{mi}$, with a high of $22.0 \mathrm{~g} / \mathrm{mi}$ and a low of $14.0 \mathrm{~g} / \mathrm{mi}$. The John Deere CNG buses averaged $10.6 \mathrm{~g} / \mathrm{mi}$ methane, with a high of $11.8 \mathrm{~g} / \mathrm{mi}$ and a low of $9.51 \mathrm{~g} / \mathrm{mi}$.

\subsection{Carbon Dioxide}

Figure 15 shows $\mathrm{CO}_{2}$ emissions. $\mathrm{CO}_{2}$ is a greenhouse gas produced by complete combustion. Neither the EPA nor CARB currently regulate $\mathrm{CO}_{2}$ emissions. However, with recently increased emphasis on the issue of global warming, there is increased focus on $\mathrm{CO}_{2}$ emissions, and $\mathrm{CO}_{2}$ emissions might be regulated in the future. In the short and medium term, voluntary incentives and increasing pressure for action by environmental groups may drive reductions in $\mathrm{CO}_{2}$ emissions. $\mathrm{CO}_{2}$ emissions averaged 3,159 g/mi from the MY 2000 DDC diesel buses and 3,346 $\mathrm{g} / \mathrm{mi}$ from the MY 2004 DDC diesel buses. $\mathrm{CO}_{2}$ emissions averaged 2,258 g/mi from the CWI CNG buses and 2,173 $\mathrm{g} / \mathrm{mi}$ from the John Deere CNG buses. 


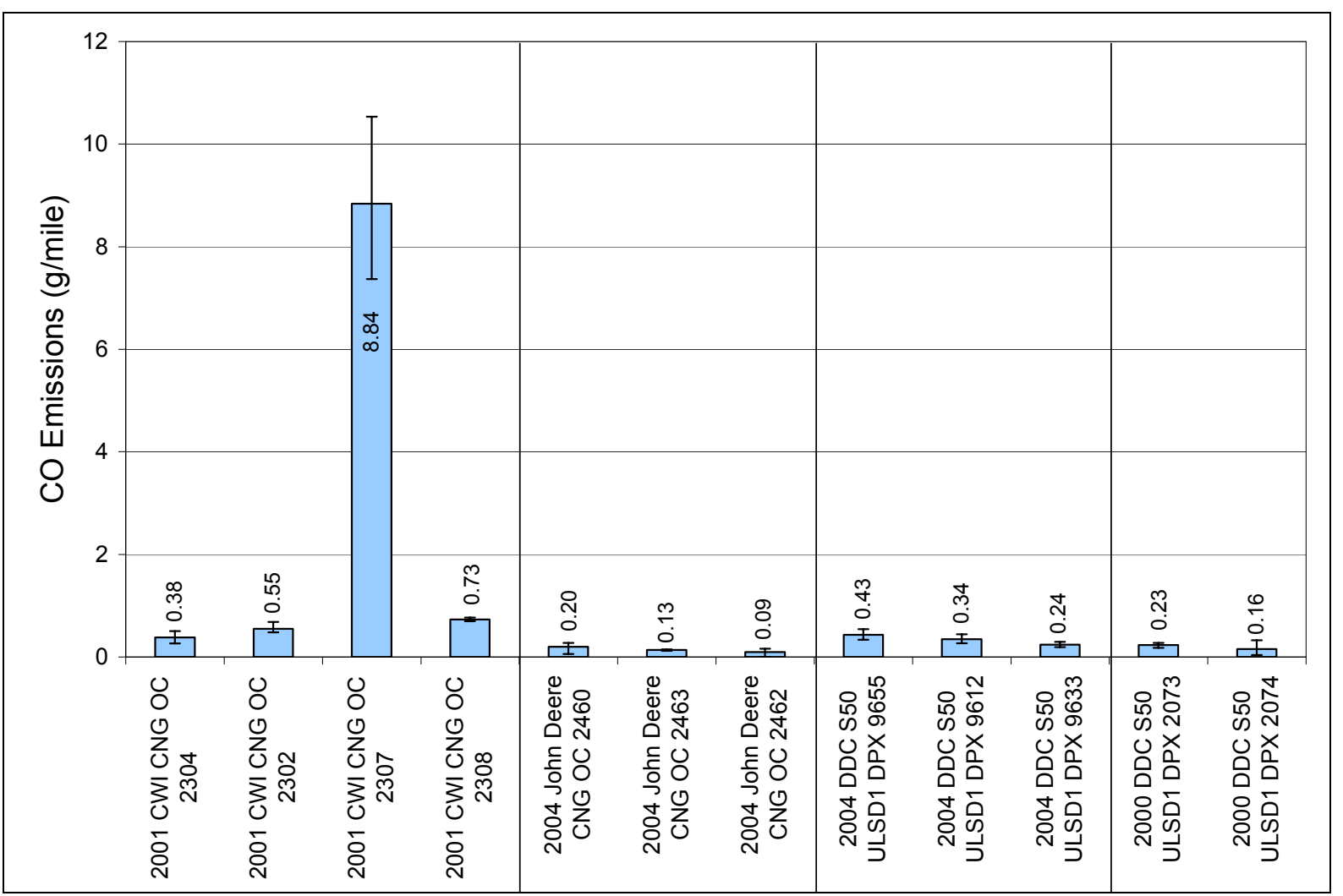

Figure 12: CO Emissions

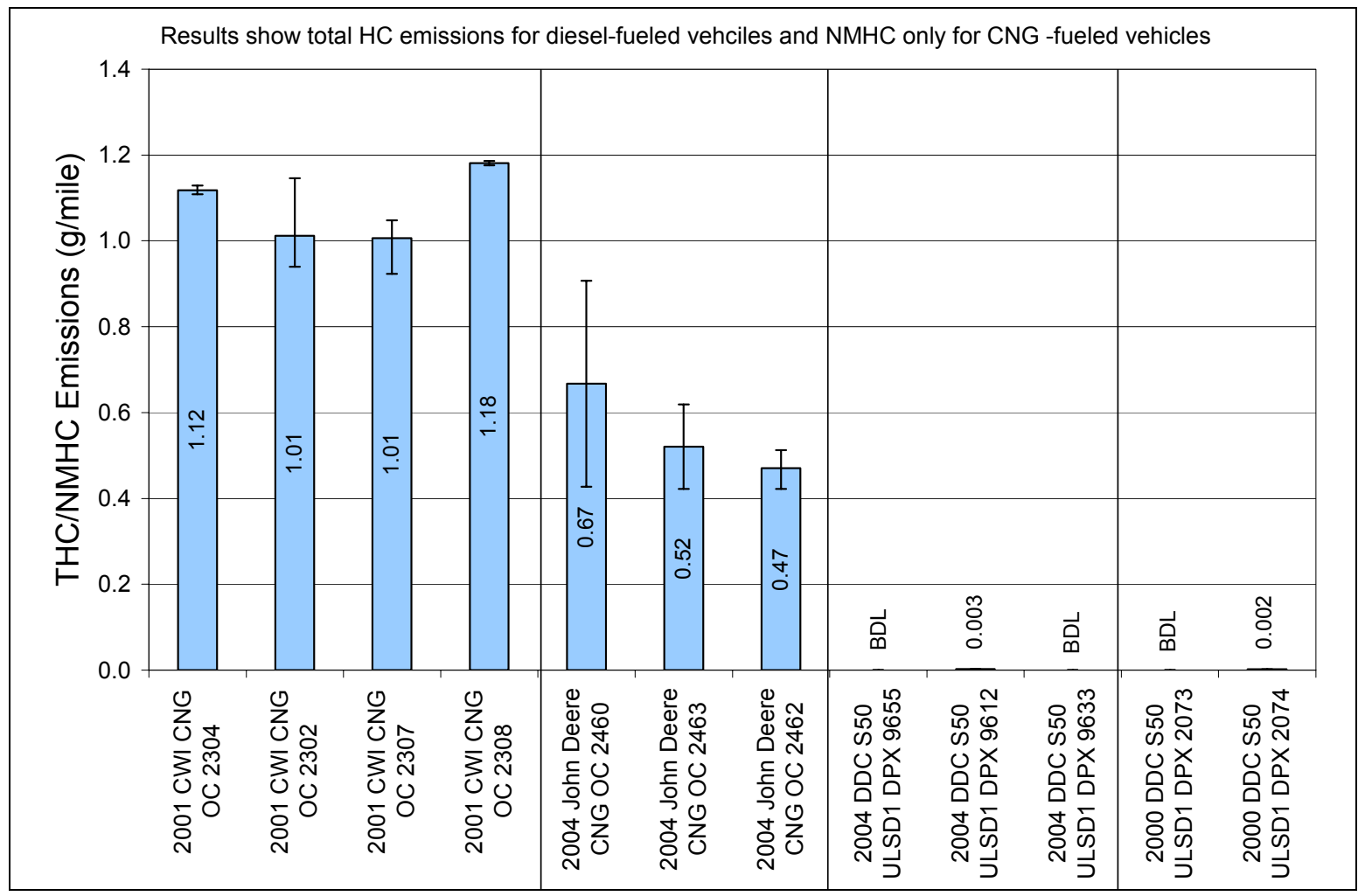

Figure 13: THC (Diesel Vehicles) and NMHC (CNG Vehicles) Emissions 


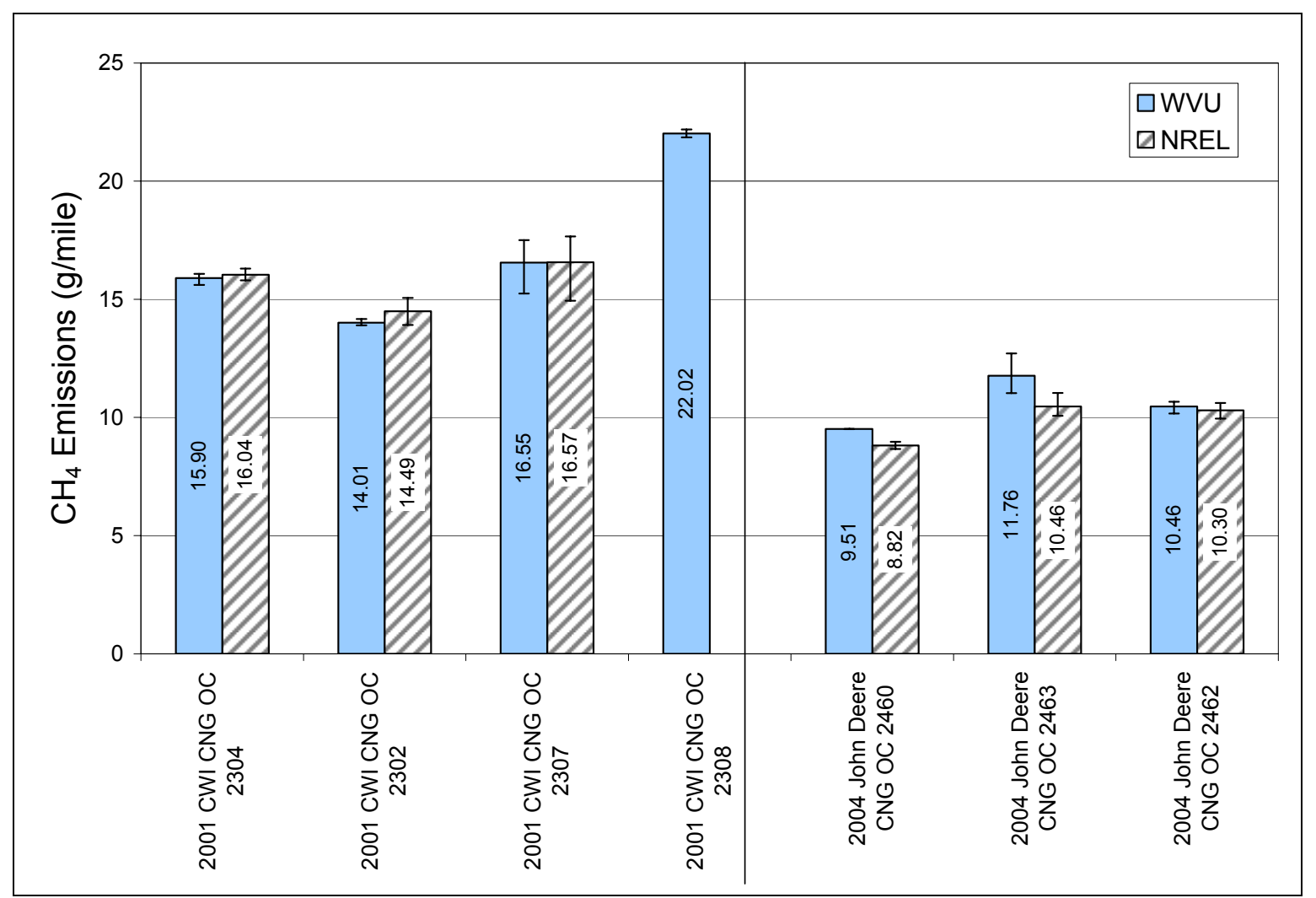

Figure 14: Methane Emissions (CNG vehicles only)

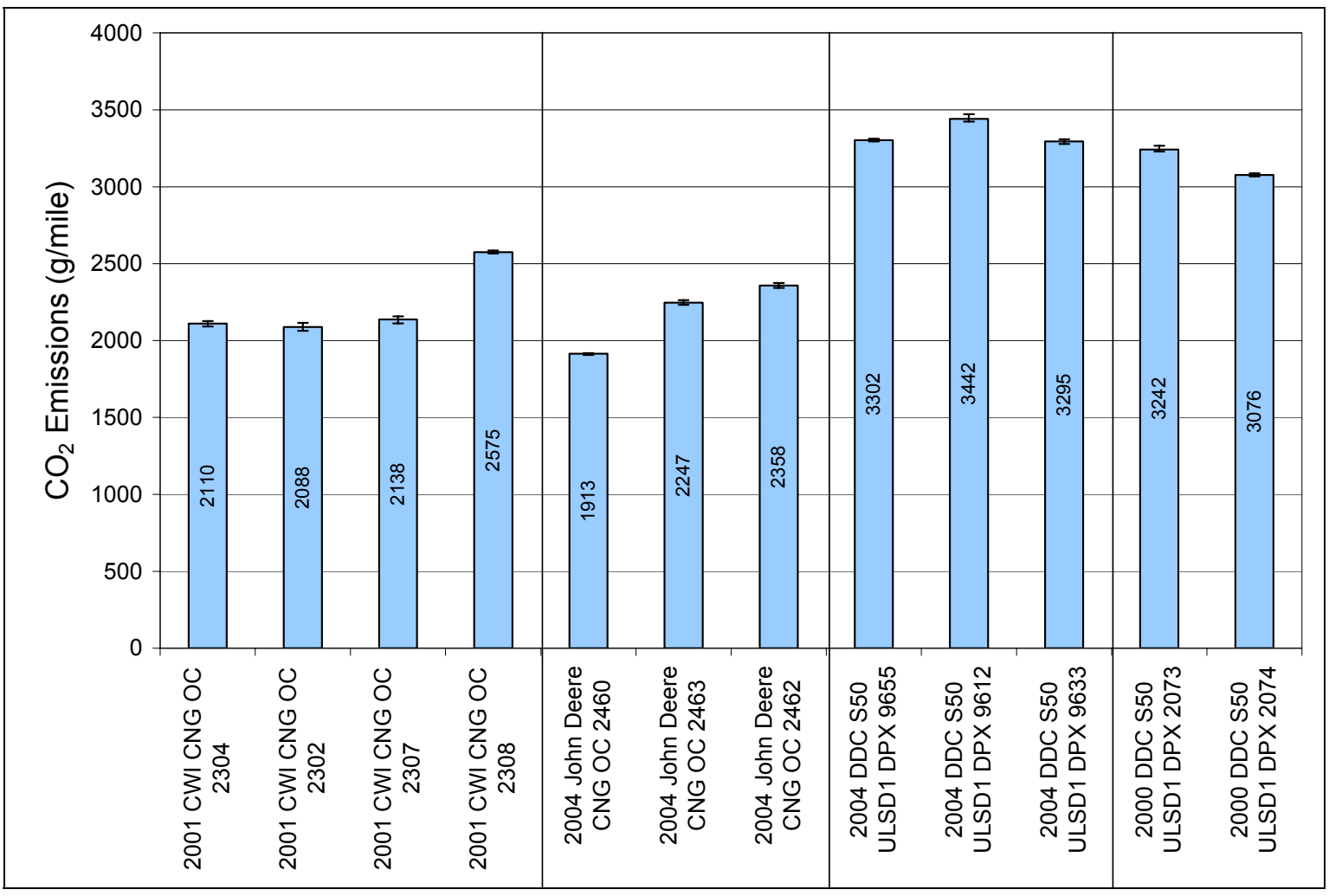

Figure 15: $\mathrm{CO}_{2}$ Emissions 


\subsection{Fuel Economy}

Fuel consumption and economy results were computed using a carbon balance, fuel properties, and measured emissions data. The carbon compounds $\left(\mathrm{CO}_{2}, \mathrm{CO}\right.$, and $\left.\mathrm{HC}\right)$ emitted in the exhaust were measured, and the fuel consumption was calculated using a carbon balance equation. Fuel economy was converted to miles per energy equivalent diesel gallon (mpeg) to facilitate comparison among the diesel and CNG buses. Fuel analysis results for the ultra-low sulfur diesel fuel and the CNG fuels are provided in Table 5 and Table 6.

The mass of carbon measured in the exhaust constituents during testing is calculated as follows:

$$
G_{S}=R_{\text {fuel }} H C_{\text {mass }}+0.429 C O_{\text {mass }}+0.273 \mathrm{CO}_{2 \text { mass }}
$$

(Equation 1)

Where $G_{S}=$ grams of carbon in the exhaust, $R_{\text {fuel }}=$ the ratio of carbon to hydrogen plus other constituents in the fuel (equals 0.75 for pure methane), $\mathrm{HC}_{\text {mass }}=\mathrm{HC}$ emissions in grams (this assumes the $\mathrm{HC}$ in the exhaust have the same carbon mass fraction as the unburned fuel), $\mathrm{CO}_{\text {mass }}$ $=\mathrm{CO}$ emissions in grams, and $\mathrm{CO}_{2 \text { mass }}=\mathrm{CO}_{2}$ emissions in grams. When a detailed fuel composition is known, $\mathrm{R}_{\text {fuel }}$ is calculated by determining the ratio of the mass of carbon in the fuel to the total mass of the fuel as shown in Table 8 for the CNG fuel. A similar calculation was performed for the diesel fuel.

Table 8: Calculation of the Carbon Weight Fraction $\left(R_{\text {fuel }}\right)$ for $C N G$

\begin{tabular}{|c|c|c|c|}
\hline & Mole \% & Mass of Carbon (g) & $\begin{array}{c}\text { Mass of Hydrogen \& } \\
\text { Others (g) }\end{array}$ \\
\hline Methane $\mathrm{CH}_{4}$ & 94.291 & $\begin{array}{r}94.291^{*}(1)^{*}(12)= \\
1,131.492\end{array}$ & $\begin{array}{r}94.291^{*}(4)^{*}(1)= \\
377.164\end{array}$ \\
\hline Ethane $\mathrm{C}_{2} \mathrm{H}_{6}$ & 3.624 & $\begin{array}{r}3.624^{*}(2)^{*}(12)= \\
86.976\end{array}$ & $3.624^{*}(6)^{*}(1)=21.744$ \\
\hline Ethene $\mathrm{C}_{2} \mathrm{H}_{4}$ & $<0.1$ & $0^{*}(2)^{*}(12)=0$ & $0^{*}(4)^{*}(1)=0$ \\
\hline Propane $\mathrm{C}_{3} \mathrm{H}_{8}$ & 0.627 & $\begin{array}{r}0.627^{*}(3)^{*}(12)= \\
22.572\end{array}$ & $0.627^{\star}(8)^{*}(1)=5.016$ \\
\hline Propylene $\mathrm{C}_{3} \mathrm{H}_{6}$ & $<0.1$ & $0^{*}(3)^{*}(12)=0$ & $0^{*}(6)^{*}(1)=0$ \\
\hline Butanes $\mathrm{C}_{4} \mathrm{H}_{10}$ & 0.213 & $\begin{array}{r}0.213^{*}(4)^{*}(12)= \\
10.224\end{array}$ & $0.213^{*}(10)^{*}(1)=2.13$ \\
\hline Butenes $\mathrm{C}_{4} \mathrm{H}_{8}$ & $<0.1$ & $0^{*}(4)^{\star}(8)=0$ & $0^{*}(8)^{*}(1)=0$ \\
\hline Pentanes $\mathrm{C}_{5} \mathrm{H}_{12}$ & 0.041 & $0.041^{*}(5)^{*}(12)=2.46$ & $0.041^{*}(10)^{*}(1)=0.492$ \\
\hline Pentenes $\mathrm{C}_{5} \mathrm{H}_{10}$ & $<0.1$ & $0^{*}(5)^{*}(10)=0$ & $0^{*}(10)^{*}(1)=0$ \\
\hline Hexanes $\mathrm{C}_{6} \mathrm{H}_{14}$ & 0.079 & $0.079^{*}(6)^{\star}(14)=5.688$ & $0.079^{*}(14)^{*}(1)=1.106$ \\
\hline $\mathrm{C}_{6}+$ & $<0.1$ & $0^{*}(6)^{\star}(12)=0$ & $0^{*}(14)^{*}(1)=0$ \\
\hline $\mathrm{CO}_{2}$ & $<0.564$ & $0.564^{*}(1)^{*}(12)=6.768$ & $0^{*}(2)^{*}(16)=0$ \\
\hline $\mathrm{CO}$ & $<0.1$ & $0^{*}(1)^{*}(12)=0$ & $0^{*}(1)^{*}(16)=0$ \\
\hline $\mathrm{O}_{2}$ & 0.003 & $0.003^{*}(0)^{*}(12)=0$ & $0.003^{*}(2)^{*}(16)=0.096$ \\
\hline $\mathrm{N}_{2}$ & 0.558 & $0.558^{*}(0)^{*}(12)=0$ & $0.558^{*}(2)^{\star}(14)=15.624$ \\
\hline $\mathrm{H}_{2}$ & $<0.1$ & $\left.+0 *(0)^{*} 12\right)=0$ & $+0^{*}(2)^{*}(1)=0$ \\
\hline Sum & & 1266.18 & 441.42 \\
\hline
\end{tabular}

(Equation 2)

The diesel energy equivalent fuel economy was calculated by computing the mass of carbon in a unit mass of CNG fuel having energy content equivalent to one gallon of CARB diesel fuel, as 
shown in Table 9. Relevant diesel fuel properties are included in Table 6. Fuel economy is then computed as follows:

$$
M P G=\left[\frac{g C / \text { equivgal }}{G_{S}}\right](\text { distance traveled })
$$

(Equation 3)

Table 9: Calculation of Energy Equivalent Fuel Economy

\begin{tabular}{|l|r|r|}
\hline & ULS Diesel \#1 & \multicolumn{1}{c|}{ CNG } \\
\hline Density & $3,142 \mathrm{~g} / \mathrm{gal}$ & $20.483 \mathrm{~g} / \mathrm{ft}^{3}$ \\
\hline Lower Heating Value & $40.70 \mathrm{BTU} / \mathrm{g}$ & $50.40 \mathrm{BTU} / \mathrm{g}$ \\
\hline $\mathbf{R}_{\text {fuel }}$ & $0.866 \mathrm{gC} / \mathrm{g}$ fuel & $0.723 \mathrm{gC} / \mathrm{g}$ fuel \\
\hline $\mathbf{g C} /$ equiv gal & $2,636 \mathrm{gC} / \mathrm{gal}$ & $1,881.7 \mathrm{gC} /$ equiv gal \\
\hline
\end{tabular}

Figure 16 shows diesel energy equivalent fuel economy results. The John Deere CNG buses averaged $3.15 \mathrm{mpeg}$, with bus number 2460 performing somewhat better than the other two buses in the group. The MY 2004 DDC diesel buses averaged $2.89 \mathrm{mpg}$. The CWI CNG buses averaged $3.01 \mathrm{mpeg}$; the fuel economy of bus number 2308 was markedly lower than the other three buses in this group. The MY 2000 DDC diesel buses averaged $3.06 \mathrm{mpg}$. These are promising fuel economy results for the CNG buses; CNG buses typically suffer a fuel economy penalty compared with diesel buses. These results will be compared with in-use fuel economy results from WMATA.

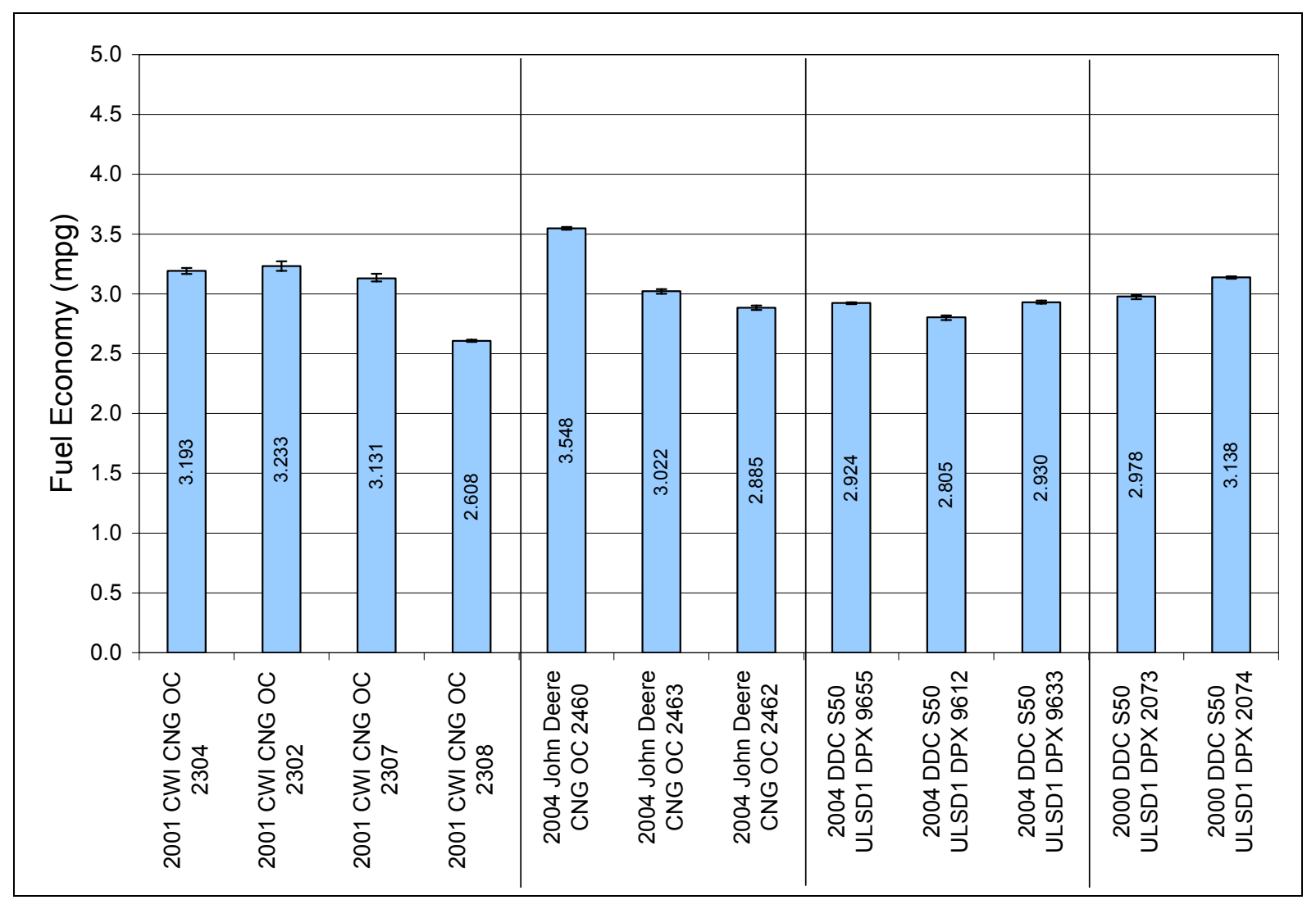

Figure 16: Diesel Energy Equivalent Fuel Economy 


\subsection{Carbonyl Emissions}

Samples were collected and analyzed to determine the levels of carbonyl (aldehyde and ketone) compounds in the vehicle exhaust and ambient background air. Results are summarized in Table 10 and Table 11. Common practice dictates that the emissions values be background corrected according to equations specified in CFR40, Part 86, Subpart N [5] of the following form:

$$
C_{\text {mass }}=\left(V_{\text {mix }}+V_{s f}\right) x\left[\frac{C_{f}}{V_{s f}}-\left(\frac{C_{b g}}{V_{b g}} x\left[1-\left(\frac{1}{D F}\right)\right]\right)\right]
$$

(Equation 4)

Where $\mathrm{C}_{\text {mass }}=$ mass of the carbonyl constituent emitted in the exhaust of the test vehicle, $\mathrm{V}_{\text {mix }}=$ total dilute exhaust volume corrected to standard conditions, $\mathrm{V}_{\mathrm{sf}}=$ total volume of sample passed through the DNPH cartridge corrected to standard conditions, $\mathrm{C}_{\mathrm{f}}=$ mass of the carbonyl constituent detected in the sample, $\mathrm{C}_{\mathrm{bg}}=$ mass of the carbonyl constituent detect in the ambient background sample, $\mathrm{V}_{\mathrm{bg}}=$ total volume of ambient air passed through the background sample cartridge, and $\mathrm{DF}$ is the dilution factor calculated as $\mathrm{DF}=13.4 / \mathrm{CO}_{2 \mathrm{e}}$ for petroleum-fueled vehicles, where $\mathrm{CO}_{2 \mathrm{e}}$ is the $\mathrm{CO}_{2}$ concentration in the diluted exhaust sample. This method is inaccurate when concentrations in the vehicle exhaust are very near the ambient background levels because DF is not an accurate representation of the dilution ratio (i.e., volume of exhaust/ volume of dilution air).

The results presented here have not been background corrected. Instead, the ambient background levels are reported along with the uncorrected foreground results. The ambient background levels are reported in units of $\mathrm{mg} / \mathrm{mi}$ to facilitate comparison with the vehicle test results. The ambient background samples were collected over a period equal to the duration of the WMATA test cycle. The ambient background results were divided by $4.25 \mathrm{mi}$, the distance traveled during the WMATA cycle.

Figure 17 shows formaldehyde emissions. Each bar represents the average uncorrected emissions value from the three repeat test runs performed on each vehicle. The diamonds with error bars show the background emissions values associated with each vehicle. Table 10 and Table 11 show tabulated results. Anomalously high background emissions values are identified by footnotes in Table 10 and Table 11 but were omitted from the data plotted in Figure 17. Other anomalously high or low test results are also highlighted in the tabulated data, but these results were NOT omitted from the averaged results shown in Figure 17. Ambient background formaldehyde levels averaged $2.380 \mathrm{mg} / \mathrm{mi}$. Formaldehyde emissions from the John Deere CNG buses averaged $8.84 \mathrm{mg} / \mathrm{mi}$. Formaldehyde emissions from the MY 2004 DDC diesel buses averaged $3.147 \mathrm{mg} / \mathrm{mi}$; these formaldehyde levels were of the same magnitude as the ambient background levels. The CWI CNG buses emitted substantially higher formaldehyde than the other bus groups, averaging $89.86 \mathrm{mg} / \mathrm{mi}$ with a low of $68.282 \mathrm{mg} / \mathrm{mi}$ and a high of 107.740 $\mathrm{mg} / \mathrm{mi}$. Formaldehyde emissions from the MY 2000 DDC diesel buses averaged $8.027 \mathrm{mg} / \mathrm{mi}$. 


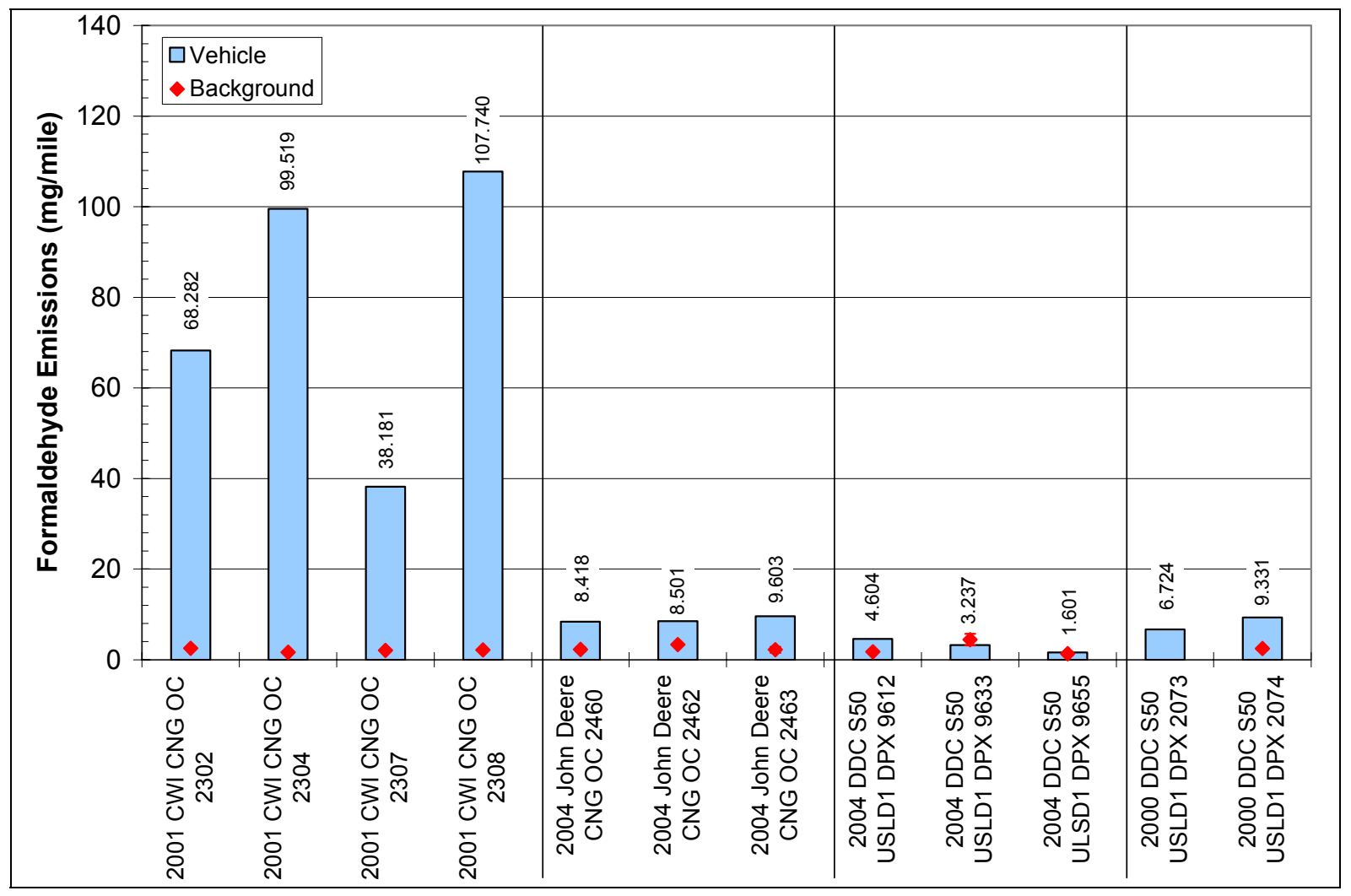

Figure 17: Formaldehyde Emissions

Figure 18 shows acetaldehyde emissions. The ambient background acetaldehyde level averaged over the test program was $2.419 \mathrm{mg} / \mathrm{mi}$; however, the data exhibited more scatter than did the background formaldehyde data. The trend closely followed the formaldehyde results: the MY 2004 DDC diesel buses exhibited the lowest acetaldehyde emissions, followed by the John Deere CNG buses and the MY 2000 DDC diesel buses. The CWI CNG buses exhibited appreciably higher acetaldehyde emissions than the other buses - only these buses produced acetaldehyde emissions that were above ambient levels.

The formaldehyde and acetaldehyde emission results from the CWI CNG buses are unusual and might indicate a malfunction with the exhaust catalyst or a maintenance/durability issue, neither of which could be verified in time for inclusion in this report. See Section 7.2 below for further discussion of these results.

Figure 19 shows acetone emissions. The average ambient background acetone level was 4.098 $\mathrm{mg} / \mathrm{mi}$, but the data exhibited significant scatter. Acetone levels in the exhaust gases were very near ambient levels. Considering the very low acetone levels in the vehicle exhaust and the variability in the ambient background levels, no clear trends are apparent among the engine and bus technologies tested.

Results for other carbonyl compounds are listed in Table 10 and Table 11. Acrolein was detected in low concentrations in the exhaust from the CWI CNG buses. Acrolein was not detected in the ambient background samples. Propanal was detected in the exhaust and ambient background 
samples, but in nearly all instances the exhaust gas levels were at or below the ambient background levels. Crotonaldehyde was detected at low concentrations in samples from CWI CNG buses 2302 and 2304. The crotonaldehyde results from MY 2004 DDC diesel bus 9655 were anomalously high. Benzaldehyde, 2-butanone, and hexaldehyde were detected in a large number of samples, but exhaust gas levels were at or below ambient background levels.

Samples were collected and analyzed on site by NREL for 1,3-butadiene, BTEX, and other HC compounds using gas chromatography methods. However, the sensitivity of the GC equipment available for the analysis was not sufficient to detect the low levels of these compounds present in the exhaust gases. Results for compounds that were detected are presented in Appendix A.

\subsection{Conclusions}

\subsection{Regulated Emissions and Fuel Economy}

Reducing $\mathrm{NO}_{\mathrm{x}}$ and $\mathrm{PM}$ emissions, particularly $\mathrm{NO}_{\mathrm{x}}$, represents the greatest challenge for heavyduty engines being developed to meet increasingly strict EPA and California emission standards. This project compared numerous regulated and unregulated emissions of CNG and diesel transit buses, including $\mathrm{NO}_{\mathrm{x}}$ and PM.

The John Deere CNG buses produced 49\% lower $\mathrm{NO}_{\mathrm{x}}$ emissions and 84\% lower PM emissions compared with the MY 2004 DDC diesel buses, and 63\% lower $\mathrm{NO}_{\mathrm{x}}$ emissions and 60\% lower PM emissions compared with the MY 2000 DDC diesel buses. The CWI CNG buses produced $6.1 \%$ higher $\mathrm{NO}_{\mathrm{x}}$ emissions and 60\% lower PM emissions compared with the MY 2004 DDC diesel buses, and 23\% lower $\mathrm{NO}_{\mathrm{x}}$ emissions and equal PM emissions compared with the MY 2000 DDC diesel buses.

Although $\mathrm{CO}$ emissions are not considered to be a great challenge in meeting future emission regulations, $\mathrm{CO}$ results from this project may prompt a closer look at the durability of specific oxidation catalysts. WMATA CWI CNG buses similar to those tested in this project were also tested 2 years ago (on a different drive cycle, the CBD cycle). $\mathrm{CO}$ emissions for one of the buses measured in the present project were almost double the $\mathrm{CO}$ emissions measured for similar buses in the past project. This might indicate that oxidation catalyst degradation or failure occurred during the 2 years of operation between the emission testing projects for this one bus. $\mathrm{CO}$ emissions from all the other buses tested were extremely low.

In addition to showing the emissions advantage of CNG buses, this project showed promising fuel economy results for the CNG buses compared with the benchmark diesel buses. The following fuel economy comparisons are made on a diesel gallon equivalent basis. The John Deere CNG buses exhibited a 9.0\% fuel economy improvement compared with the MY 2004 DDC diesel buses and a 2.9\% improvement compared with the MY 2000 DDC diesel buses. The CWI buses exhibited fuel economy that was 4.2\% higher than the MY 2004 DDC diesel buses and 1.6\% lower than the MY 2000 DDC diesel buses. Both CNG engines use lean burn technology. 


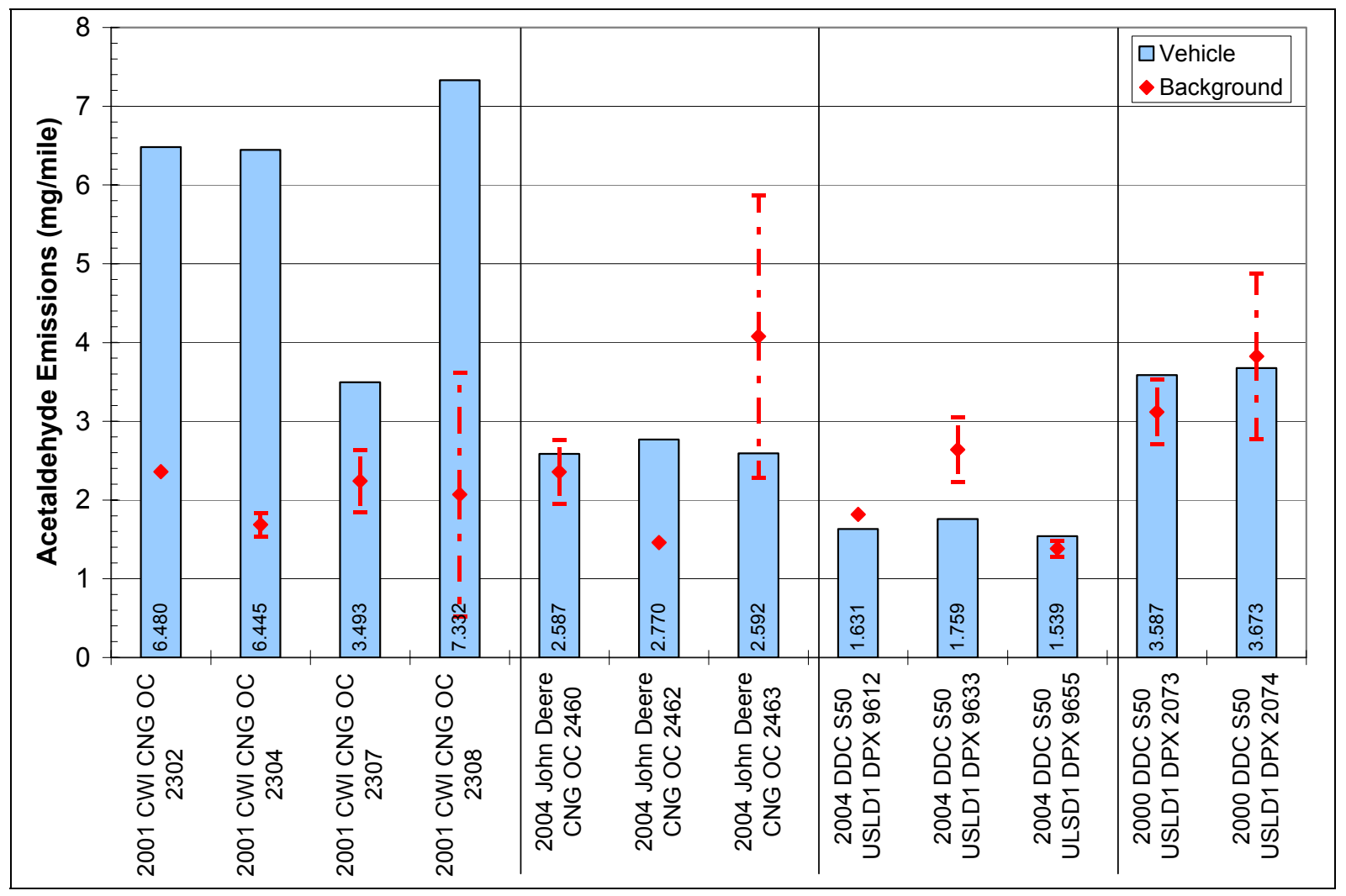

Figure 18: Acetaldehyde Emissions

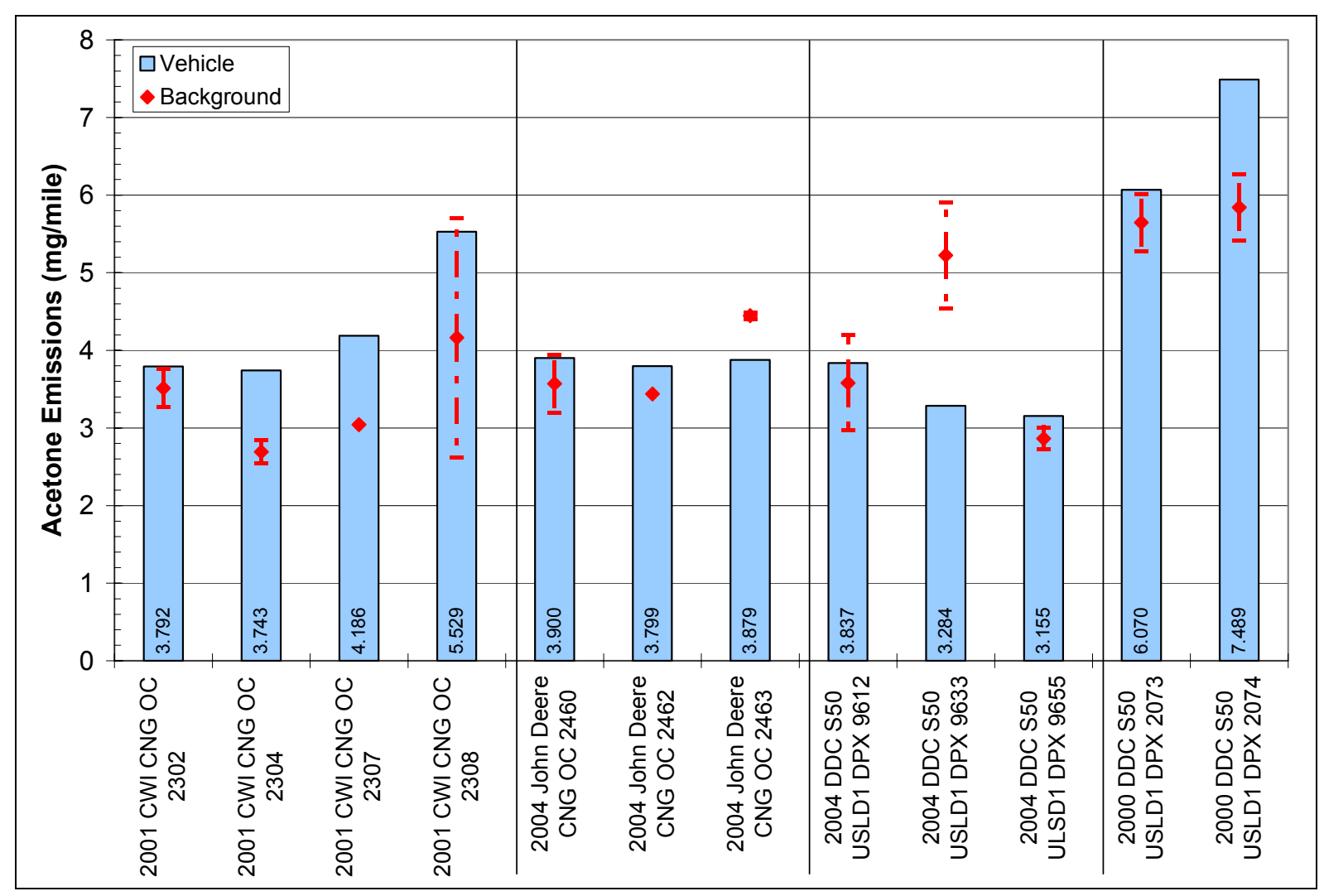

Figure 19: Acetone Emissions 
Table 10: Diesel Vehicle Carbonyl Emissions (mg/mi)

\begin{tabular}{|c|c|c|c|c|c|c|c|c|c|c|c|c|c|c|c|c|c|}
\hline Bus \# & Run \# & 这 & $\begin{array}{l}\frac{0}{0} \\
\frac{0}{0} \\
\frac{0}{3} \\
\frac{0}{0}\end{array}$ & 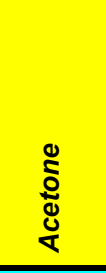 & $\begin{array}{l}\frac{5}{0} \\
\frac{0}{0} \\
\frac{0}{\alpha}\end{array}$ & $\begin{array}{l}\frac{\pi}{2} \\
\frac{\pi}{2} \\
\frac{2}{2}\end{array}$ & 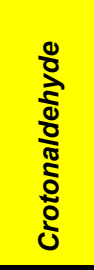 & 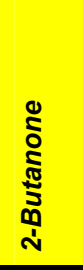 & 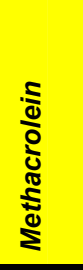 & 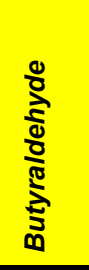 & 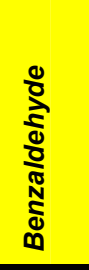 & $\begin{array}{l}\frac{0}{0} \\
\frac{0}{0} \\
\frac{0}{0} \\
\frac{0}{0} \\
\frac{0}{0} \\
0\end{array}$ & $\frac{\frac{\pi}{2}}{\frac{\pi}{2}}$ & $\begin{array}{l}\frac{0}{0} \\
\frac{1}{0} \\
\frac{0}{0} \\
\frac{0}{0} \\
\frac{0}{0}\end{array}$ & 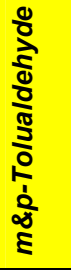 & $\begin{array}{l}\frac{1}{d} \\
\frac{d}{d} \\
\frac{\pi}{\pi} \\
\frac{\pi}{1}\end{array}$ & 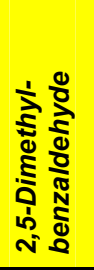 \\
\hline \multicolumn{18}{|c|}{ Diesel Buses with MY 2000 DDC Series 50 Engines } \\
\hline \multirow{5}{*}{2073} & Backgnd & $6.718^{1}$ & 3.529 & 6.014 & & 0.833 & & 1.384 & & & 1.853 & & & & & & \\
\hline & $4166-1$ & 8.227 & 1.785 & 3.355 & & & & & & & 0.558 & & & & & 0.768 & \\
\hline & $4166-2$ & 5.523 & 5.204 & 6.586 & & 0.801 & & 0.678 & & & & & & & & 0.827 & \\
\hline & $4166-3$ & 6.423 & 3.771 & 8.268 & & 0.727 & & & & & & & 0.669 & & & 0.923 & \\
\hline & Backgnd & 5.674 & 2.705 & 5.282 & & 0.520 & & 1.238 & & & 1.742 & & & & & 1.080 & 0.514 \\
\hline \multirow{5}{*}{2074} & Backgnd & 2.068 & 4.876 & 6.267 & & 1.031 & & 1.639 & & 0.703 & 0.000 & & & & & 0.820 & \\
\hline & $4169-1$ & 9.620 & 3.062 & 7.623 & & 0.636 & & 1.077 & & & 1.128 & & & & & 1.121 & \\
\hline & $4169-2$ & 9.418 & 5.061 & 7.659 & & 0.899 & & 1.313 & & & 1.084 & & & & & 0.916 & \\
\hline & $4169-4$ & 8.955 & 2.897 & 7.185 & & 0.633 & & 1.142 & & & 0.763 & & & & & 0.858 & \\
\hline & Backgnd & 2.853 & 2.772 & 5.418 & & 1.179 & & 1.191 & & & 0.934 & & & & & 1.060 & \\
\hline \multicolumn{18}{|c|}{ Diesel Buses with MY 2004 DDC Series 50 Engines } \\
\hline \multirow{5}{*}{9612} & Backgnd & 1.597 & 1.816 & 2.966 & & 0.414 & & 0.627 & & & & & & & & 0.594 & 0.385 \\
\hline & 4151-1 & 3.827 & 1.166 & 3.411 & & 0.377 & & 0.506 & & & 0.771 & & 0.801 & & & 0.480 & \\
\hline & $4151-3$ & 6.341 & 2.708 & 4.332 & & 0.397 & & 1.410 & & 0.682 & 0.785 & & 0.496 & & & 1.285 & \\
\hline & $4151-4$ & 3.645 & 1.019 & 3.768 & & 0.397 & & 0.662 & & & 1.123 & & 0.512 & & & 0.524 & \\
\hline & Backgnd & 1.940 & 4.369 & 4.193 & & 0.633 & & 1.049 & & & 1.067 & & & & & 0.737 & 0.348 \\
\hline \multirow{5}{*}{9633} & Backgnd & 3.129 & 2.231 & 4.540 & & 0.725 & & 1.021 & & & & & & & & 1.060 & \\
\hline & $4163-1$ & 3.934 & 0.520 & $0.812^{2}$ & & 0.214 & & & & 0.564 & & & 1.191 & & & 0.734 & \\
\hline & 4163-2 & 3.828 & 2.776 & 5.927 & & 0.745 & & 1.172 & & & 0.637 & & 1.109 & & & 0.938 & \\
\hline & $4163-3$ & 1.951 & 1.981 & 3.113 & & 0.644 & & & & & & & 0.878 & & & 0.728 & \\
\hline & Backgnd & 5.712 & 3.050 & 5.909 & & 0.818 & & & 0.818 & & & 2.029 & & & & & \\
\hline \multirow{5}{*}{9655} & Backgnd & $0.934^{3}$ & 1.278 & 3.007 & & 0.530 & & 1.032 & & & 1.534 & & & & & 0.837 & \\
\hline & 4148-1 & 1.610 & 1.447 & 3.276 & & & $8.032^{4}$ & & & & 0.601 & & 0.846 & & & 0.338 & \\
\hline & $4148-2$ & 1.587 & 1.320 & 3.119 & & 0.335 & $8.869^{4}$ & & & & 0.264 & & 0.847 & & & & \\
\hline & $4148-3$ & 1.606 & 1.850 & 3.072 & & 0.336 & $4.456^{4}$ & & 0.303 & & 0.701 & & & & & & \\
\hline & Backgnd & 1.738 & 1.486 & 2.723 & & 0.721 & & 1.003 & & & 1.251 & 0.871 & & & 8 & 0.659 & \\
\hline
\end{tabular}

\footnotetext{
${ }^{1}$ High ambient background

${ }^{2}$ Anomalously low result

${ }^{3}$ Low ambient background

${ }^{4}$ Anomalously high result

Blank cells indicate that the compound was not detected in the sample.
} 
Table 11: CNG Vehicle Carbonyl Emissions (mg/mi)

\begin{tabular}{|c|c|c|c|c|c|c|c|c|c|c|c|c|c|c|c|c|c|}
\hline Bus \# & Run \# & 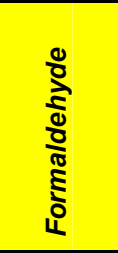 & 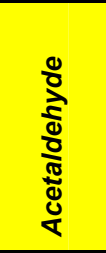 & 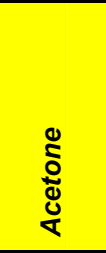 & $\begin{array}{l}\frac{5}{0} \\
\frac{0}{0} \\
\frac{0}{4}\end{array}$ & $\begin{array}{l}\bar{\Xi} \\
\frac{\pi}{0} \\
\frac{2}{2}\end{array}$ & 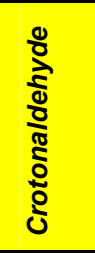 & 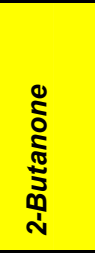 & 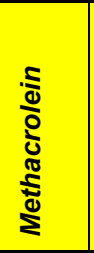 & $\frac{0}{\frac{0}{0}}$ & $\begin{array}{l}\frac{0}{\delta} \\
\frac{1}{d} \\
\frac{\delta}{\pi N} \\
\frac{N}{0} \\
\infty\end{array}$ & 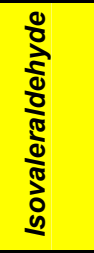 & 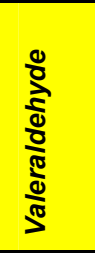 & 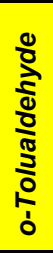 & है & 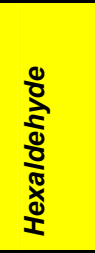 & 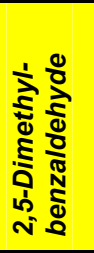 \\
\hline \multicolumn{18}{|c|}{ CNG Buses with MY 2001 CWI C Gas Plus Engines } \\
\hline \multirow{5}{*}{2302} & Backgnd & $4.598^{5}$ & $5.139^{5}$ & 3.759 & & 0.813 & & 1.543 & & 0.590 & 1.925 & & 0.246 & & & 1.081 & \\
\hline & $4142-1$ & 68.122 & 7.158 & 4.226 & 0.372 & 1.001 & & 1.491 & & 0.732 & 2.560 & & 0.266 & & 1.077 & 1.479 & 0.880 \\
\hline & $4142-2$ & 67.305 & 6.737 & 3.720 & 0.312 & 0.903 & 0.173 & 1.012 & & 0.441 & 1.912 & & & & 0.000 & 1.118 & \\
\hline & $4142-3$ & 69.418 & 5.545 & 3.431 & 0.283 & 0.687 & 0.442 & 0.917 & & & 1.816 & & & & 0.325 & 0.879 & \\
\hline & Backgnd & 2.527 & 2.360 & 3.267 & & 0.525 & & 0.946 & & & 2.268 & & & & & 0.810 & \\
\hline \multirow{5}{*}{2304} & Backgnd & 1.474 & 1.838 & 2.839 & & 0.585 & 0.191 & & 0.848 & 0.289 & 0.933 & & & & 0.287 & 1.028 & \\
\hline & 4139-2 & 101.530 & 6.159 & 3.413 & 0.418 & 0.622 & & 0.903 & & & 1.185 & & & & & 0.823 & 0.634 \\
\hline & 4139-3 & 98.616 & 6.341 & 3.917 & 0.421 & 0.709 & 0.388 & & 0.610 & & 1.806 & 1.072 & & & & 1.047 & 0.561 \\
\hline & $4139-4$ & 98.410 & 6.836 & 3.899 & 0.468 & 0.685 & 0.362 & 0.511 & 0.655 & & 1.541 & & & & & 1.741 & 0.345 \\
\hline & Backgnd & 1.794 & 1.536 & 2.545 & & 0.592 & & 0.637 & & & 1.062 & 0.759 & & & & 0.576 & \\
\hline \multirow{5}{*}{2307} & Backgnd & 1.908 & 1.845 & 3.043 & & 0.386 & & 0.830 & & & 0.440 & & & & & & \\
\hline & $4145-1$ & 36.960 & 3.067 & 2.967 & 0.179 & 0.580 & & 0.502 & 1.483 & & & & & & & 0.689 & \\
\hline & $4145-2$ & 39.255 & 3.861 & 5.561 & 0.334 & 0.697 & & 0.984 & & & 0.843 & & & & & 0.763 & \\
\hline & $4145-3$ & 38.329 & 3.551 & 4.031 & & 0.657 & & 1.085 & & & 1.481 & & & & & 1.272 & \\
\hline & Backgnd & 2.205 & 2.637 & $6.845^{5}$ & & 0.727 & & 0.892 & & & 1.431 & & & & & 0.901 & 0.385 \\
\hline \multirow{4}{*}{2308} & Backgnd & $8.454^{5}$ & 3.622 & 5.705 & & 0.966 & & 1.079 & & & & & & & & 1.527 & \\
\hline & $4198-1$ & 107.364 & 7.449 & 5.492 & 0.587 & 1.169 & & 0.000 & 0.953 & & 1.596 & & & & & & \\
\hline & $4198-2$ & 108.115 & 7.215 & 5.566 & 0.607 & 0.939 & & 1.558 & & & & & & & & & \\
\hline & Backgnd & 2.171 & 0.516 & 2.625 & & 0.359 & & & & & 0.830 & & & & 1.133 & & \\
\hline \multicolumn{18}{|c|}{ CNG Buses with MY 2004 John Deere 6081H Engines } \\
\hline \multirow{5}{*}{2460} & Backgnd & 1.828 & 2.761 & 3.193 & & 0.467 & & 0.874 & & & & & & & & 0.735 & \\
\hline & $4154-1$ & 8.058 & 2.871 & 4.159 & & 0.924 & & 1.023 & & & 0.546 & & & & & 0.939 & 0.369 \\
\hline & $4154-2$ & 8.587 & 2.563 & 4.281 & & 0.610 & & 1.134 & & & & & & & & 0.849 & \\
\hline & 4154-3 & 8.607 & 2.328 & 3.260 & & 0.349 & & 1.047 & & & & & & & & 0.922 & \\
\hline & Backgnd & 2.679 & 1.953 & 3.946 & & 0.611 & & 1.097 & & & 0.761 & & & & 4.883 & 0.926 & \\
\hline \multirow{4}{*}{2462} & Backgnd & 3.351 & 1.460 & 3.439 & & & & 1.146 & & & & & & & & 0.867 & \\
\hline & $4160-1$ & 8.557 & 3.353 & 3.673 & & 0.573 & & 0.979 & & & 1.222 & & & & & 0.918 & \\
\hline & $4160-2$ & 8.494 & 2.053 & 3.565 & & & & 0.886 & & & 1.305 & & & & & 0.906 & \\
\hline & $4160-3$ & 8.452 & 2.903 & 4.158 & & 0.622 & & 1.027 & & & 2.119 & & & & & 0.905 & \\
\hline \multirow{5}{*}{6463} & Backgnd & 1.573 & 5.870 & 4.405 & & 1.231 & & 1.801 & & 0.781 & & & & & & 1.031 & \\
\hline & $4157-2$ & 10.232 & 2.794 & 4.071 & & 0.638 & & 1.686 & & & 1.528 & & & & & 0.949 & \\
\hline & $4157-3$ & 8.049 & 2.222 & 3.405 & & 0.672 & & 0.852 & & & 1.731 & & & & 0.651 & 0.785 & \\
\hline & $4157-5$ & 10.528 & 2.760 & 4.161 & & 0.527 & & 0.972 & & & 1.668 & & & & & 0.913 & \\
\hline & Backgnd & 2.843 & 2.285 & 4.491 & & 1.050 & & 1.055 & & 0.388 & 1.797 & & & & & 1.045 & \\
\hline
\end{tabular}

${ }^{5}$ High Ambient Background

Blank cells indicate that the compound was not detected in the sample. 


\subsection{Carbonyl/Toxic Emissions}

Formaldehyde and acetaldehyde emissions from the diesel buses and the John Deere CNG buses were very low, approaching ambient background levels. The CWI CNG buses produced formaldehyde and acetaldehyde emissions that were above ambient background levels and were markedly higher than the other bus groups. This result is unusual. It may indicate a malfunction with the exhaust catalyst or a maintenance/durability issue, neither of which could be verified in time for inclusion in this report.

Other carbonyl emissions were not detected at levels that could be distinguished from ambient levels, indicating that the levels are extremely low for these emissions from all the vehicles tested. An attempt was made to characterize 1,3-butadiene and BTEX emissions. However, the gas chromatography equipment available for this study did not have sufficient sensitivity to detect the low levels of 1,3-butadiene and BTEX in the vehicle exhaust. The NREL ReFUEL laboratory is examining options to acquire more sensitive equipment for future projects.

In general, the diesel and natural gas exhaust catalyst systems tested did well in reducing these toxic emissions to near ambient levels and, in some cases, to levels so low that the instruments could not detect them. However, enough anomalous readings occurred to suggest that the longterm durability of heavy-duty engine catalysts is uncertain and warrants further study.

\subsection{Overall Conclusions}

Overall, the CNG buses are showing significant improvements in fuel economy and show progress toward meeting the increasingly stringent EPA emission regulations that all heavy-duty engines will have to meet in 2006-2010 and beyond. In general, measured $\mathrm{NO}_{\mathrm{x}}$ and PM emissions and fuel economy for the CNG vehicles in this study were comparable to or better than the benchmark diesel buses, indicating significant improvements in CNG engine technology and demonstrating that alternative fuels such as natural gas still offer valuable energy security and environmental benefits for transit fleets.

\subsection{References}

1. Melendez, M. Evaluating the Emissions Reduction Benefits of WMATA Natural Gas Buses. NREL/FS-540-33280. Golden, CO: National Renewable Energy Laboratory, June 2003.

2. Wang, W.; Gautam, M.; Sun, X.; Bata, R.; Clark, N.; Palmer, M.; Lyons, D. "Emissions Comparisons of Twenty-Six Heavy Duty Vehicles Operated on Conventional and Alternative Fuels.” SAE Paper 932952. Warrendale, PA: Society of Automotive Engineers, 1993.

3. Clark, N.; Gautam, M.; Bata, R.; Lyons, D. "Design and Operation of a New Transportable Laboratory for Emissions Testing of Heavy-Duty Trucks and Buses," International Journal of Vehicle Design: Heavy Vehicle Systems; Vol. 2, Nos. 3/4, 1995; p. 285-299. 
4. Wang, W.; Bata, R.; Lyons, D.; Clark, N.; Palmer, M.; Gautam, M.; Howell, A.; Rapp, B. "Transient Response in a Dynamometer Power Absorption System." SAE Paper 920252. Warrendale, PA: Society of Automotive Engineers, 1992.

5. Code of Federal Regulations, Title 40, Part 86, Subpart N. "Protection of Environment." U.S. Government Printing Office, 2002.

6. Siegl W.O.; Richert J.F.O.; Jensen R.E.; Schuetzle D.; Swarin S.J.; Loo J.F.; Prostak A.; Nagy D.; Schlenker A.M. "Improved Emissions Speciation Methodology for Phase II of the Auto/Oil Air Quality Improvement Research Program Hydrocarbons and Oxygenates.” SAE Technical Paper 930142. Warrendale, PA: Society of Automotive Engineers, 1993. 


\section{Appendix A: Gas Chromatography Results}

The following table gives gas chromatography results in units of $\mathrm{g} / \mathrm{mi}$. Blank cells indicate the compound was not detected in the sample.

\begin{tabular}{|c|c|c|c|c|c|c|c|}
\hline Bus \# & Run \# & Methane & Ethene & $\begin{array}{c}\text { Ethane + } \\
\text { Acetylene }\end{array}$ & Propane & Isobutylene & Butane \\
\hline \multicolumn{8}{|c|}{ MY 2000 DDC Series 50 Diesel with DPX } \\
\hline \multirow{4}{*}{2073} & Background & 0.4778 & & & & 0.0287 & \\
\hline & $4166-1$ & 0.4416 & & & & & \\
\hline & $4166-2$ & 0.3992 & & & & & \\
\hline & $4166-3$ & 0.3955 & & & & & \\
\hline \multirow{4}{*}{2074} & Background & 0.4704 & & & & 0.0257 & \\
\hline & $4169-1$ & 0.4200 & & & & & \\
\hline & $4169-2$ & 0.4451 & & & & & \\
\hline & $4169-4$ & 0.4057 & & & & & \\
\hline \multicolumn{8}{|c|}{ MY 2004 DDC Series 50 Diesel with EGR and DPX } \\
\hline \multirow{5}{*}{9612} & Background & 0.3366 & & & & & \\
\hline & $4151-1$ & 0.3126 & & & & & \\
\hline & $4151-3$ & 0.3013 & & & & & \\
\hline & $4151-4$ & 0.2583 & & & & & \\
\hline & Background & 0.3159 & & & & & \\
\hline \multirow{5}{*}{9633} & Background & 0.6790 & & & & 0.0186 & \\
\hline & $4163-1$ & 0.4767 & & & & & \\
\hline & $4163-2$ & 0.4628 & & & & & \\
\hline & $4163-3$ & 0.4501 & & & & & \\
\hline & Background & 0.3290 & & & & & \\
\hline \multirow{4}{*}{9655} & $4148-1$ & 0.3112 & & & & & \\
\hline & $4148-2$ & 0.3093 & & & & & \\
\hline & $4148-3$ & 0.3055 & & & & & \\
\hline & Background & 0.3209 & & & & & \\
\hline \multicolumn{8}{|c|}{ MY 2001 CWI C Gas Plus CNG with Oxidation Catalyst } \\
\hline \multirow{5}{*}{2302} & Background & 0.4148 & & & & & \\
\hline & $4142-1$ & 15.157 & 0.0841 & 0.7034 & 0.1123 & & 0.0334 \\
\hline & $4142-2$ & 14.011 & 0.1506 & 0.6828 & 0.0971 & & 0.0264 \\
\hline & $4142-3$ & 14.594 & 0.0268 & 0.7015 & 0.1057 & & 0.0318 \\
\hline & Background & 0.3625 & & & & & \\
\hline \multirow{5}{*}{2304} & Background & 0.4263 & & & & & \\
\hline & $4139-2$ & 16.128 & 0.1719 & 0.7862 & 0.1823 & & 0.0422 \\
\hline & 4139-3 & 16.408 & 0.1745 & 0.7987 & 0.1586 & & 0.0443 \\
\hline & $4139-4$ & 15.905 & 0.1371 & 0.8135 & 0.1662 & & 0.0465 \\
\hline & Background & 0.3833 & & & & & \\
\hline \multirow{5}{*}{2307} & Background & 0.3605 & & & & & \\
\hline & $4145-1$ & 15.041 & 0.0841 & 0.6924 & 0.0796 & & 0.0190 \\
\hline & $4145-2$ & 17.217 & 0.1506 & 0.8471 & 0.1053 & & 0.0297 \\
\hline & $4145-3$ & 17.759 & 0.1268 & 0.8408 & 0.1002 & & 0.0284 \\
\hline & Background & 0.4280 & & & & & \\
\hline \multicolumn{8}{|c|}{ MY 2004 John Deere 6081H CNG with Oxidation Catalyst } \\
\hline \multirow{5}{*}{2460} & Background & 0.435 & & & & & \\
\hline & $4154-1$ & 8.560 & & 0.2320 & & & \\
\hline & $4154-2$ & 8.817 & & 0.3161 & & & \\
\hline & $4154-3$ & 9.125 & & 0.2737 & & & \\
\hline & Background & 0.4573 & & & & & \\
\hline \multirow{4}{*}{2462} & Background & 0.5113 & & & & & \\
\hline & $4160-1$ & 10.511 & & 0.2507 & & & \\
\hline & $4160-2$ & 10.127 & & 0.3255 & & & \\
\hline & $4160-3$ & 10.79 & & 0.3367 & & & \\
\hline \multirow{5}{*}{2463} & Background & 0.4477 & & & & & \\
\hline & $4157-2$ & 10.238 & & 0.3089 & & & \\
\hline & $4157-3$ & 10.443 & & 0.3369 & & & \\
\hline & $4157-5$ & 11.202 & & 0.2835 & & & \\
\hline & Background & 0.5179 & & & & & \\
\hline
\end{tabular}




\section{REPORT DOCUMENTATION PAGE}

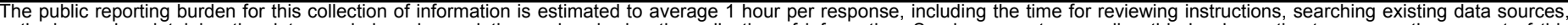

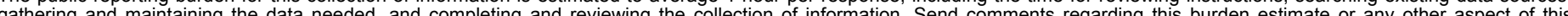

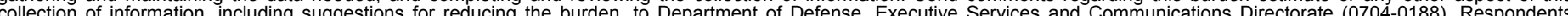

should be aware that notwithstanding any other provision of law, no person shall be subject to any penalty for failing to

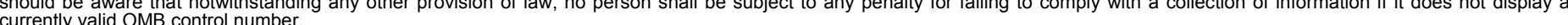

PLEASE DO NOT RETURN YOUR FORM TO THE ABOVE ORGANIZATION.

\begin{tabular}{l|l|l|l} 
1. REPORT DATE $(D D-M M-Y Y Y Y)$ & 2. REPORT TYPE & 3. DATES COVERED (FrOm - TO)
\end{tabular}

December 2005

Technical Report

4. TITLE AND SUBTITLE

Emission Testing of Washington Metropolitan Area Transit Authority

(WMATA) Natural Gas and Diesel Transit Buses

6. AUTHOR(S)

M. Melendez, J. Taylor, W.S. Wayne, D. Smith, and J. Zuboy 5a. CONTRACT NUMBER

DE-AC36-99-GO10337

5b. GRANT NUMBER

5c. PROGRAM ELEMENT NUMBER

5d. PROJECT NUMBER

NREL/TP-540-36355

5e. TASK NUMBER

FC05.9000

5f. WORK UNIT NUMBER
7. PERFORMING ORGANIZATION NAME(S) AND ADDRESS(ES)

National Renewable Energy Laboratory

1617 Cole Blvd.

Golden, CO 80401-3393
8. PERFORMING ORGANIZATION REPORT NUMBER

NREL/TP-540-36355

9. SPONSORING/MONITORING AGENCY NAME(S) AND ADDRESS(ES)

10. SPONSOR/MONITOR'S ACRONYM(S) NREL

11. SPONSORING/MONITORING AGENCY REPORT NUMBER

12. DISTRIBUTION AVAILABILITY STATEMENT

National Technical Information Service

U.S. Department of Commerce

5285 Port Royal Road

Springfield, VA 22161

13. SUPPLEMENTARY NOTES

14. ABSTRACT (Maximum 200 Words)

An evaluation of emissions of natural gas and diesel transit buses operated by the Washington Metropolitan Area Transit Authority (WMATA).

15. SUBJECT TERMS

natural gas; transit buses; diesel buses; natural gas buses; WMATA; emissions

\begin{tabular}{|c|c|c|}
\hline $\begin{array}{l}\text { a. REPORT } \\
\text { Unclassified }\end{array}$ & $\begin{array}{l}\text { b. ABSTRACT } \\
\text { Unclassified }\end{array}$ & $\begin{array}{l}\text { c. THIS PAGE } \\
\text { Unclassified }\end{array}$ \\
\hline
\end{tabular}

\begin{tabular}{l|l} 
17. LIMITATION \\
OF ABSTRACT \\
UL
\end{tabular}

19a. NAME OF RESPONSIBLE PERSON

19b. TELEPHONE NUMBER (Include area code) 